INSTITUTO DE PESQUISAS ENERGÉTICAS E NUCLEARES

Autarquia Associada à Universidade de São Paulo

\title{
AVALIAÇÃO DO PADRÃO DE RESPOSTA DE IMUNOGLOBULINAS EM DIFERENTES LINHAGENS DE CAMUNDONGOS FRENTE À INFECÇÃO POR T.cruzi
}

ANDRÉIA DOS SANTOS SILVA

Dissertação apresentada como parte dos requisitos para obtenção do Grau de Mestre em Ciências na Área de Tecnologia Nuclear - Aplicações

Orientadora:

Prof $^{a}$. Dra. Nanci do Nascimento

São Paulo

2006 
INSTITUTO DE PESQUISAS ENERGÉTICAS E NUCLEARES Autarquia Associada à Universidade de São Paulo

\section{AVALIAÇÃO DO PADRÃO DE RESPOSTA DE IMUNOGLOBULINAS EM DIFERENTES LINHAGENS DE CAMUNDONGOS FRENTE À INFECÇÃO POR T.cruzi}

ANDRÉIA DOS SANTOS SILVA

Dissertação apresentada como parte dos requisitos para obtenção do Grau de Mestre em Ciências na Área de Tecnologia Nuclear - Aplicações

Orientadora:

Prof $^{\mathrm{a}}$. Dra. Nanci do Nascimento

São Paulo

2006 


\section{AGRADECIMENTOS}

A Deus pelo milagre da vida.

À Dra . Nanci do Nascimento, minha orientadora, pela oportunidade de realização desse trabalho e orientação.

Ao Dr. Heitor Franco de Andrade Jr, pela colaboração e confiança de ter aberto as portas do Laboratório de Protozoologia do Instituto de Medicina Tropical de São Paulo.

À Dra . Eufrosina Setsu Umezawa, por sua colaboração e apoio.

À Roselaine Pereira Alvim Cardoso, pelos ensinamentos transmitidos e apoio técnico.

À Dra. Lígia Ely Morganti Ferreira Dias, por possibilitar a utilização de seu laboratório.

Ao Dr. Patrick Jack Spencer, pelo apoio, por suas sugestões e esclarecimentos nos momentos de dúvida.

À Janaína Baptista Alves, por todo o auxílio prestado ao longo do desenvolvimento desse trabalho.

À Rosa Maris Szarota, por toda sua colaboração e ensinamentos transmitidos.

À Rute Batista, por sua paciência e dedicação em todos os momentos.

Aos demais colegas, funcionários do IPEN e do IMT-FMUSP, pelo apoio e companheirismo.

Ao Dr. Luiz Augusto Corrêa Passos, em especial, por toda a sua colaboração, contribuições e apoio prestado ao longo de todo o desenvolvimento desse trabalho. 


\section{LISTA DE FIGURAS}

Página

$\begin{array}{ll}\text { FIGURA 1: Trypanosoma cruzi. } & 07\end{array}$

$\begin{array}{ll}\text { FIGURA 2: Ciclo de vida do T. cruzi. } & 08\end{array}$

$\begin{array}{ll}\text { FIGURA 3: Triatoma infestans. } & 09\end{array}$

$\begin{array}{ll}\text { FIGURA 4: Panstrongylus megistus. } & 10\end{array}$

FIGURA 5: Rhodnius prolixus. $\quad 10$ 


\section{LISTA DE TABELAS}

Página

TABELA 1 - Infecção experimental dos animais das linhagens C57BL/6 e A/J, após a inoculação de diferentes concentrações de $T$. cruzi.

TABELA 2 - Comparação das linhagens susceptível, resistente e híbrida após inoculo de T. cruzi.

TABELA 3 - Infecção experimental dos animais isogênico recombinantes (BXA1 e BXA7) após inoculo de $T$. cruzi.

TABELA 4 - Infecção experimental dos animais isogênicos recombinantes (BXA2 e BXA4) após inoculo de T. cruzi.

TABELA 5 - Comparação das linhagens BXA1 e BXA2 após inoculo de T. cruzi. 


\section{LISTA DE GRÁFICOS}

Página

GRÁFICO 1 - Ensaio imunoenzimático para avaliação de anticorpos específicos (IgG Total) com soro proveniente da $6^{\circ}$ sangria com diferentes diluições ( 1:50, 1:100, 1:200)

GRÁFICO 2 - Ensaio imunoenzimático para a produção de anticorpos específicos (IgG Total) com soro proveniente da $1^{\circ}$ sangria.

GRÁFICO 3 - Ensaio imunoenzimático para a produção de anticorpos específicos (IgG Total) com soro proveniente da $2^{\circ}$ sangria.

GRÁFICO 4 - Ensaio imunoenzimático para a produção de anticorpos específicos (IgG Total) com soro proveniente da $3^{\circ}$ sangria.

GRÁFICO 5 - Ensaio imunoenzimático para a produção de anticorpos específicos (IgG Total) com soro proveniente da $4^{\circ}$ sangria.

GRÁFICO 6 - Ensaio imunoenzimático para a produção de anticorpos específicos (IgG Total) com soro proveniente da $5^{\circ}$ sangria.

GRÁFICO 7 - Ensaio imunoenzimático para a produção de anticorpos específicos (IgG Total) com soro proveniente da $6^{\circ}$ sangria.

GRÁFICO 8 - Ensaio imunoenzimático para a produção de anticorpos específicos (IgG Total) com soro proveniente da $7^{\circ}$ sangria.

GRÁFICO 9 - Ensaio imunoenzimático para avaliação da produção de Anticorpos específicos (IgG1, IgG2a e IgG2b) com soro proveniente da $1^{\circ}$ sangria de animais da linhagem $A / J$.

GRÁFICO 10 - Ensaio imunoenzimático para avaliação da produção de anticorpos específicos (IgG1, IgG2a e IgG2b) com soro proveniente da $1^{\circ}$ e $6^{\circ}$ sangrias de animais da linhagem C57BL/6.

GRÁFICO 11 - Ensaio imunoenzimático para avaliação da produção de anticorpos específicos (IgG1, IgG2a e IgG2b) com soro proveniente da $1^{\circ}$ e $6^{\circ}$ sangrias de animais da linhagem B6AF1.

GRÁFICO 12 - Ensaio imunoenzimático para avaliação da produção de anticorpos específicos (IgG1, IgG2a e IgG2b) com soro proveniente da $1^{\circ}$ e $6^{\circ}$ sangrias de animais da linhagem BXA1.

GRÁFICO 13 - Ensaio imunoenzimático para avaliação da produção de anticorpos específicos (IgG1, IgG2a e IgG2b) com soro proveniente da $1^{\circ}$ e $6^{\circ}$ sangrias de animais da linhagem BXA2. 


\section{SUMÁRIO}

Páginas

1 - INTRODUÇÃO $\quad 01$

2 - CONTEXTO TEÓRICO 03

$\begin{array}{ll}2.1 \text { Histórico } & 03\end{array}$

2. 2 Formas da Doença e Sintomas 03

2. 3 Modos de Transmissão 04

2. 3.1 Transmissão Natural 04

2. 3. 2 Transmissão Transfusional 05

2. 3. 3 Transmissão Congênita 05

2. 3. 4 Transmissão por Via Digestiva 06

2. 3. 5 Transmissão Acidental em Laboratório 06

2. 4 O Parasito 06

2. 5 Ciclo Biológico 07

2. 6 Vetores 09

2. 7 Animais Reservatórios 11

2. 8 Genética de Camundongos 12

2. 9 Aspectos Imunológicos 15

2. 9. 1 Leucócitos 16

2. 9. 1. 1 Macrófagos 16

2. 9. 1. 2 Neutrófilos 16

2. 9. 1. 3 Linfócitos 17

2. 9. 2 Substâncias Solúveis $\quad 18$

2. 9. 2. 1 Anticorpos 18

2. 9. 2. 2 Sistema do Complemento 20

2. 9. 2. 3 Citocinas 20

3 - OBJETIVO GERAL 21

4 - MATERIAL E MÉTODO 22

$\begin{array}{ll}\text { 4.1 Material } & 22\end{array}$

4. 1. 1 O Parasito 22

4.1. 2 Animais $\quad 22$ 
4. 1. 3 Reagentes 22

4. 2 Métodos 23

4. 2. 1 Manutenção do T. cruzi em Cultivo 23

4. 2. 1.1 Obtenção do Antígeno de T. cruzi 23

4. 2. 1. 2 Teste de Infecção com Diferentes Concentrações de T. cruzi 23

4. 2. 1. 3 T. cruzi Sangüícolas para os Testes de Infecção 24

4. 2. 2 Manutenção dos Animais $\quad 24$

4. 2. 2. 1 Infecção Experimental das Linhagens Parentais Originais $\begin{array}{ll}\text { com T. cruzi } & 24\end{array}$

4. 2. 2. 2 Obtenção e Infecção dos Híbridos B6AF1 25

4. 2. 2. 3 Obtenção dos Animais Recombinantes Isogênicos 25

4. 2. 2. 4 Obtenção de Soro das Linhagens Parentais Originais, dos Híbridos B6AF1 e da Linhagem Recombinante Isogênica 25

4. 2. 3 Ensaio Imunoenzimático (ELISA) 26

5 - RESULTADOS $\quad 27$

5. 1 Infecção Experimental com T. cruzi das Linhagens C57BL/6 e A/J 27

5. 2 Infecção Experimental com T. cruzi dos Híbridos B6AF1 28

5. 3 Infecção Experimental dos Animais das Linhagens

Recombinantes Isogênicas $\quad 29$

5. 4 Ensaio Imunoenzimático (ELISA) 30

6 - DISCUSSÃO 37

7 - CONCLUSÕES $\quad 44$

REFERÊNCIAS BIBLIOGRÁFICAS $\quad 45$ 


\section{AVALIAÇÃO DO PADRÃO DE RESPOSTA DE IMUNOGLOBULINAS EM DIFERENTES LINHAGENS DE CAMUNDONGOS FRENTE À INFECÇÃO POR T.cruzi}

Andréia dos Santos Silva

\section{RESUMO}

$O$ presente trabalho realizou-se com diferentes linhagens de camundongos (A/J, C57BL/6, B6AF1, BXA1 e BXA2) que foram desafiados com diferentes doses da cepa $Y$ de $T$. cruzi. O objetivo foi avaliar o padrão de resposta de imunoglobulinas produzidas por estas linhagens e para tanto, amostras de soros foram analisadas pelo método imunoenzimático. A partir dos resultados obtidos observou-se que todas as linhagens apresentaram uma resposta superior para IgG2a e IgG2b, quando comparados ao IgG1. Indicando um padrão Th1 que expressa resposta imunológica celular. As diferentes linhagens utilizadas nessa pesquisa apresentam padrões de resposta imunológica também diferentes frente à infecção por $T$. cruzi. Animais da linhagem C57BL/6 mostraram-se resistentes a infecção, enquanto que os animais da linhagem $A / J$ mostraram-se susceptíveis, corroborando com a literatura. Os animais da linhagem híbridos B6AF1 foram mais resistentes à infecção que seu parental original C57BL/6. Sua resposta imunológica apresenta traços tanto do parental original $\mathrm{A} / \mathrm{J}$ quanto do $\mathrm{C} 57 \mathrm{BL} / 6$. Os animais da linhagem BXA1 puderam ser considerados resistentes à infecção, mas não apresentaram o mesmo controle observado nos animais das linhagens B6AF1 e C57BL/6. Os animais da linhagem BXA2 foram considerados susceptíveis à infecção, mas a controlaram por um período maior, sobrevivendo assim, por tempo superior àquele observado na linhagem $A / J$. Os resultados obtidos indicam que a subclasse de imunoglobulinas IgG2b desempenha importante papel na resistência à cepa $Y$ de $T$. cruzi. 


\title{
RESPONSE PATTERN'S OF IMMUNOGLOBULINS EVALUATION IN DIFFERENT LINEAGES OF MICE INFECTED WITH T.cruzi
}

\author{
Andréia dos Santos Silva
}

\begin{abstract}
The present work has employed different mice lineages (A/J, C57BL/6, B6AF1, BXA1 and BXA2) that were challenged with different doses of $T$. cruzi. The objective was to evaluate the pattern of immunoglobulins response presented by resistant and susceptible mice to $T$. cruzi as well as the lineages developed from the matting between them. So that evaluation was done by using lineages serums' sample, analyzed by ELISA`s method. In agreement with the results observed all the lineages presented higher response to $\lg 22 a$ and $\lg G 2 b$, if compared with the titles to $\lg G 1$. IgG1 immunoglobulins involve a type Th2 pattern response which expressed allergic immunological responses, while IgG2 involves a pattern response Th1 that expresses cellular immunological response. The different lineages used in this research also presented different immunological response pattern by the infection with $T$. cruzi. Mice of the lineage C57BL/6 are resistant to the infection, while the animals of the lineage $A / J$ are susceptible. The animals of the lineage B6AF1 are more resistant to the infection than their original parental C57BL/6. The immunological response developed by hybrid mice present traces of both susceptible and resistant parental $\mathrm{A} / \mathrm{J}$ and C57BL/6, respectively. The animals of the lineage BXA1 can be considered resistant to the infection, but they don't present the same control as that presented by those of the lineages B6AF1 and C57BL/6. The animals of the lineage BXA2 can be considered susceptible to the infection, but they can control it for a long period, surviving like this, longer than the animals of the lineage $A / J$. In addition it was observed that the IgG2b immunoglobulins are very important to the resistance of mice to $T$. cruzi infection.
\end{abstract}




\section{1 - INTRODUÇÃO}

A doença de Chagas é uma parasitose tecidual e hemática, de caráter endêmico em extensas regiões do continente americano. Tem evolução geralmente crônica e é causada por um protozoário flagelado, Trypanosoma cruzi, transmitido ao homem e a vários mamíferos sensíveis por hemípteros hematófagos da subfamília Triatominae (NEVES, 1983).

No início do século $X X$, esta doença era uma enzootia presente em populações de animais silvestres, de espécies variadas. As mudanças no ambiente, decorrentes da ocupação humana, modificaram este panorama, agravando o problema do ponto de vista epidemiológico. Cerca de 16 a 18 milhões de pessoas estão infectadas e o número de pessoas expostas ao risco chaga a 100 milhões. (WHO, 2003).

Esta tripanossomíase está entre os principais problemas de saúde da América do Sul, afetando milhões de pessoas, apresentando alto impacto na morbidade e mortalidade (WHO, 2003).

Devido à ausência de vacinas ou disponibilidade, em grande escala, de tratamento específico, a principal estratégia de controle tem sido a prevenção da transmissão, principalmente na eliminação do vetor e no controle da transfusão sangüínea (GOLDENBERG \& KRIEGER, 1997).

Entretanto, a ocorrência de casos novos demonstra que estas medidas, ainda carecem de investigação científica, com o propósito de ampliar a eficiência em seu emprego.

Diferentes linhas de estudos são traçadas por vários pesquisadores, sempre com o propósito de encontrar ou uma vacina ou um tratamento eficaz para a doença de Chagas.

Assim, a observação da acentuada diferença na resistência de pessoas infectadas com $T$. cruzi, conduziu à hipótese de que a constituição genética do hospedeiro poderia influenciar o desenvolvimento da doença e a sobrevida dos doentes (PASSOS, 2003). 
A investigação de resistência a infecções requer, sob este ponto de vista, o emprego de modelos in vivo, porém com composição genética e sanitária controlada (RANGEL et al, 1994; FESTING, 1999).

Pesquisadores, então, passaram a investigar a genética de camundongos e estudar modelos animais de doenças humanas buscando ferramentas para 0 entendimento dos mecanismos de controle da infecção.

As estratégias adotadas para estes tipos de estudos baseiam-se na utilização de acasalamentos programados, realizados entre linhagens isogênicas não relacionadas, que apresentam fenótipos diferentes quanto à resistência ou susceptibilidade à doença (FORTIN et al, 2002).

A análise das infecções experimentais com o T. cruzi, empregando estas linhagens, revelou a importância da constituição genética do hospedeiro na sobrevivência e apontou para a necessidade de se realizar experimentos especificamente desenhados, com o propósito de esclarecer a influência de genes envolvidos no fenômeno da resistência (WRIGHTSMAN et al, 1982; CORSINI et al, 1980).

Neste contexto, o uso de um delineamento experimental que associe acasalamentos programados, entre animais selecionados com o parasito, contribuirá na obtenção de modelos ideais à investigação do fenômeno da resistência à cepa $Y$ do T. cruzi (PASSOS, 2003), revelando o padrão de resposta imunológica apresentado por eles. 


\section{2 - CONTEXTO TEÓRICO}

\subsection{Histórico}

A doença de Chagas ou Tripanossomíase americana foi descoberta pelo médico sanitarista Carlos Justiniano Ribeiro das Chagas - Carlos Chagas - em 1909. Este brasileiro descobriu a doença e descreveu praticamente todos os seus aspectos. Quando Carlos Chagas realizava uma campanha contra malária que atingia operários na construção de um trecho da Estrada de Ferro Central do Brasil, ao norte de Minas Gerais, ao trazer exames de uma menina doente, encontrou tripanosomas em seu sangue. Ao examinar posteriormente as fezes de insetos existentes na região e o sangue de animais mamíferos, constatou também a

presença dos mesmos parasitas. Carlos Chagas pode, desta maneira, descrever o agente causador, o transmissor e o modo de transmissão da doença, como também comprovar a existência de vertebrados que são reservatórios silvestres e domésticos do parasita, esclarecendo assim os aspectos básicos da epidemiologia da doença (ALBARRACIN et al, 1999; AVILA et al, 1993).

Além disso, com a colaboração de Gaspar Viana, Eurico Vilela e Magarinos Torres, desvendou a complexa patologia da nova entidade mórbida, sua evolução, anatomia patológica e métodos de diagnóstico; anteviu sua extensão epidemiológica e importância social, e indicou os caminhos para sua profilaxia (CASTRO et al, 1994).

\section{2 Formas da Doença e Sintomas}

Descrevem-se na literatura três fases da doença de Chagas, produzida pelo $T$. cruzi: aguda, indeterminada e crônica.

A fase inicial é a aguda, caracterizada por febre, linfodenopatia e hepatoesplenomegalia. Quando a porta de entrada dos tripanosomas é a conjuntiva ocular, pode ocorrer um edema bipalpebral, unilateral, denominado, em homenagem aos pesquisadores que o identificaram inicialmente, "sinal de Romaña-Mazza". 
Quando o parasito penetra por outros locais da superfície corporal, a lesão produzida recebe o nome de "chagoma de inoculação". Com freqüência, a fase aguda passa despercebida, pois seus sintomas podem confundir-se com os de diversas infecções. Entretanto, em alguns pacientes, principalmente crianças ou indivíduos imunodeficientes, quadros meníngeos graves e de insuficiência cardíaca podem estar associados e ocorrer óbito (ALBARRACIN et al, 1999; AVILA et al, 1993).

A gravidade da infecção depende também de outros fatores, entre os quais a virulência do parasito, o tamanho do inóculo e a susceptibilidade do paciente afetado. A fase subseqüente, conhecida como de latência ou indeterminada, não apresenta sintomatologia importante do ponto de vista clínico e pode se prolongar por vários anos. Um paciente nessa fase pode desconhecer sua condição de portador assintomático da doença e transmitir involuntariamente a infecção por mecanismos diversos. É aceita a idéia de que a maior parte dos chagásicos persiste nessa fase pelo resto de suas vidas (ALBARRACIN et al, 1999; AVILA et al, 1993).

Do conjunto dos infectados, uma proporção pequena de indivíduos evolui para a fase denominada crônica, durante a qual são identificáveis sintomas de comprometimento cardíaco (miocardite grave), com aumento do volume do coração (cardiomegalia) ou digestivo, com aumento do diâmetro de regiões do trato digestivo (megaesôfago, megacólon etc.). Há, nesta fase, gradativa redução da qualidade de vida e da capacidade de trabalho dos doentes, que passam a necessitar de atenção médica constante (ALBARRACIN et al, 1999; AVILA et al, 1993).

\section{3 Modos de Transmissão}

\section{3.1 Transmissão Natural}

O mecanismo de transmissão natural do T. cruzi ao homem é o que se dá por intermédio do inseto vetor. As condições infra-humanas em que vive grande parte das populações rurais na América Latina favorecem sobremaneira a propagação da endemia chagásica. As casas de pau-a-pique com paredes barreadas, tão comuns no interior de nosso País, servem de abrigo natural aos triatomíneos, que se ocultam 
nas frestas e rachaduras das paredes, de onde saem à noite para sugar o sangue das pessoas durante o sono (CASTRO et al, 1994).

A picada do triatomíneo no momento do repasto é geralmente indolor, não sendo percebida pela vítima durante o sono. A vítima, então, coça o local da picada e promove a entrada dos tripomastigotas, presentes nas fezes e urina do inseto, em sua pele. As regiões descobertas do corpo, essencialmente a face e os membros superiores, são os locais mais atingidos. Eventualmente podem ocorrer reações alérgicas cutâneas no local da picada do inseto (CASTRO et al, 1994).

\section{3. 2 Transmissão Transfusional}

A doença de Chagas pode ser adquirida pela transfusão de sangue e seus derivados. A chance de transmissão em uma única transfusão de sangue de um doador chagásico é de 13 a 23\%, na dependência da parasitemia do doador, da infectividade da cepa, da quantidade de sangue transfundido e da resistência do receptor (CASTRO et al, 1994).

A transmissão pode igualmente ocorrer com a transfusão de plasma, o que se pode evitar com a liofilização deste (CASTRO et al, 1994).

\section{3. 3 Transmissão Congênita}

A transmissão se dá através da placenta, onde são encontradas células parasitadas com ninhos de amastigotas, especialmente nas células de Hofbauer do estroma vilositário. Têm sido descritos casos de parasitismo da placenta sem que ocorra a transmissão ao feto (CASTRO et al, 1994).

A transmissão congênita ocorre em apenas uma pequena proporção de mães chagásicas e parece estar na dependência da cepa de $T$. cruzi e da competência imunológica da placenta (BITTECOURT et al, 1984).

A infecção fetal pelo $T$. cruzi é causa freqüente de abortos. O maior número de casos de recém-nascidos infectados se encontra entre prematuros com peso inferior a 2000g (BITTENCOURT et al, 1984). 


\section{3. 4 Transmissão por Via Digestiva}

A transmissão via oral tem sido admitida com base em surtos de microepidemias, relacionadas, aparentemente, com a ingestão de alimentos contaminados. Alguns casos já registrados estavam relacionados com a ingestão de alimento contaminado com urina de gambá, animal onívoro e sinantrópico considerado um dos principais reservatórios do $T$. cruzi. Experimentalmente, a transmissão por via digestiva foi comprovada por Dias-Hungria e colaboradores e por Lainson e colaboradores (CASTRO et al, 1994).

\section{3. 5 Transmissão Acidental em Laboratório}

A transmissão acidental em laboratório tem ocorrido entre pesquisadores da doença de Chagas que manipulam culturas de $T$. cruzi ou sangue de animais infectados. É importante o uso precoce de drogas tripanossomicidas sempre que houver suspeita de infecção (BRENER, 1980).

\section{4 O Parasito}

O T. cruzi é um protozoário da classe Mastigophora, capaz de evoluir num hospedeiro vertebrado e num vetor invertebrado. No vertebrado, apresenta-se no sangue, sob a forma alongada e flagelada de tripomastigota, caracterizada por um grande cinetoplasto terminal ou subterminal. Sua outra localização é intracelular, onde se apresenta após sofrer mudanças regressivas, arredondando-se e perdendo o flagelo tornando-se amastigotas. A forma sangüínea é extremamente móvel, medindo aproximadamente $20 \mu$ em seu eixo maior. Os amastigotas são imóveis, medem 2 a $4 \mu$ de diâmetro e geralmente se apresentam em conglomerados, no interior das células parasitadas (NEVES, 1983).

No vetor invertebrado, encontram-se as formas polares em tripomastigotas e amastigotas, bem como as intermediárias fusiformes, denominadas epimastigotas, e outras arredondadas e com flagelo livre, os esferomastigotas. O desenvolvimento 
dessas formas se dá basicamente nos dois terços distais do tubo digestivo do inseto. No intestino terminal, vão situar-se inúmeros tripomastigotas em final de ciclo, os tripanosomas metacíclicos, que são as formas mais infectantes do T. cruzi, prontas a contaminar novo hospedeiro vertebrado através das excretas do inseto vetor (NEVES, 1983).

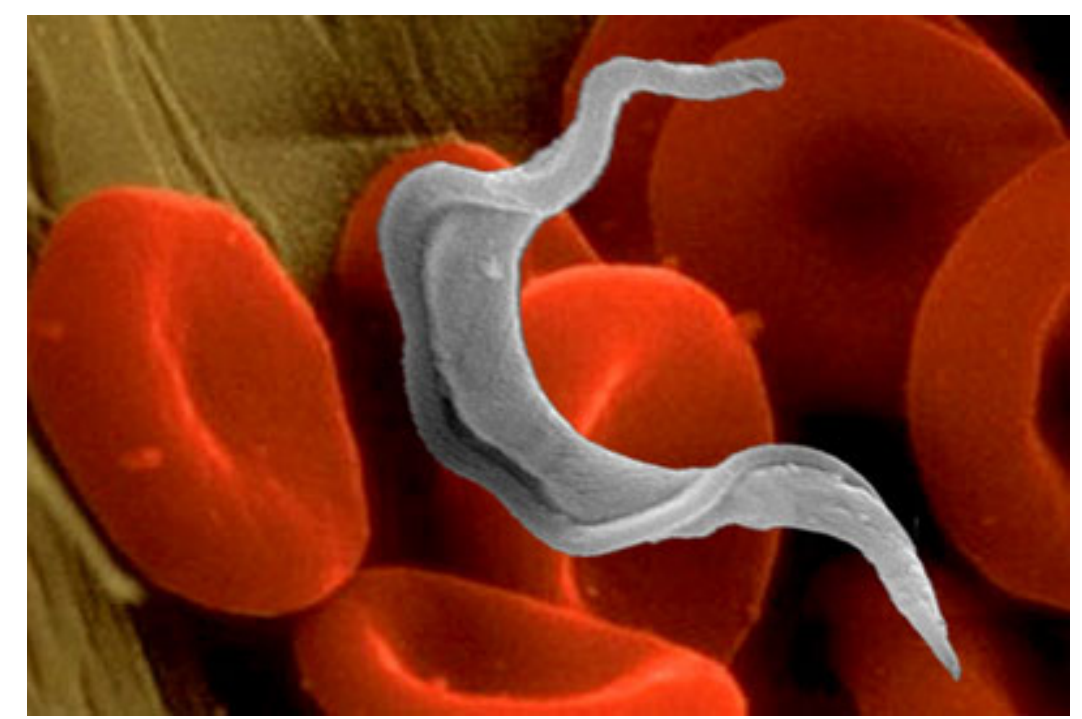

FIGURA 1: Trypanosoma cruzi, forma tripomastigota, que circula no sangue. WHO - World Health Organization, Geneve, 2003.

Cepas diferentes do T. cruzi vêm sendo evidenciadas por meio de parâmetros morfológicos, comportamento no laboratório, virulência, sensibilidade a drogas, diferentes tropismos no interior dos vertebrados etc. Tal fato apresenta grande importância prática, podendo ser arrolado como elemento explicativo para diferenças regionais observadas quanto aos padrões clínicos da doença humana e à vulnerabilidade terapêutica aos mesmos agentes medicamentosos (NEVES, 1983).

\section{5 Ciclo Biológico}

O T. cruzi possui um ciclo biológico complexo (BRENER, 1980) e várias cepas, que diferem quanto à epidemiologia, patogenia, resposta ao tratamento, bioquímica ou imunogenicidade (PASSOS, 2003). 


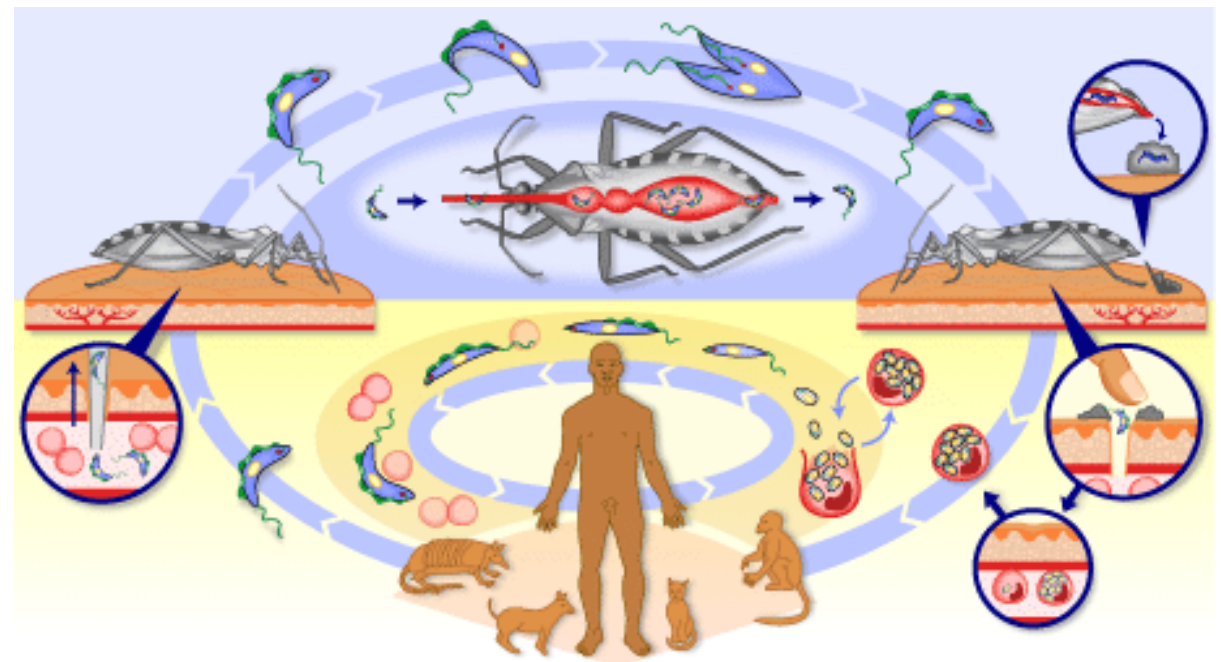

FIGURA 2: Ciclo de vida do T. cuzi em mamíferos sensíveis e no inseto vetor. WHO - World Health Organization, Geneve, 2003.

$\mathrm{Na}$ natureza, o ciclo do T. cruzi envolve dois hospedeiros, um inseto triatomíneo e um mamífero. Quando o triatomíneo alimenta-se com o sangue de um mamífero infectado pelo parasito, o mesmo ingere parasitos na forma tripomastigota, que é a forma que circula no sangue. Estes tripomastigotas transformam-se em epimastigotas na porção anterior do intestino do inseto. Diferentemente dos tripomastigotas que são formas infectantes e não-replicativas, os epimastigotas são capazes de se multiplicar e não são infectantes. Após vários ciclos de replicação, os epimastigotas migram através do intestino do inseto vetor e nas porções terminais, diferenciam-se em tripomastigotas metacíclicos, que são formas infectantes. Durante o repasto de sangue do inseto no vertebrado, ocorre a dilatação do abdome do triatomíneo e as formas tripomastigotas metacíclicas são liberadas nas fezes e urina do inseto, penetrando no interior do hospedeiro vertebrado através da pele ou através da mucosa. Uma vez na circulação, os tripomastigotas metacíclicos interiorizam-se em células, seja por fagocitose promovida pelos macrófagos, seja por penetração ativa em células não-fagocíticas, como células musculares. No interior das células do mamífero, os tripomastigotas metacíclicos transformam-se nas formas amastigotas. Estas são as formas que apresentam um flagelo diminuto e são capazes de se replicar intracelularmente. Após vários ciclos de replicação, quando a célula do hospedeiro já está repleta de amastigotas, ocorre a transformação destas formas em tripomastigotas que são liberadas na corrente sangüínea após a lise 
celular. Estas formas tripomastigotas são capazes de infectar novas células ou podem ser ingeridas, através da picada, por triatomíneos durante o repasto de sangue, e o ciclo recomeça (GOLDENBERG e KRIEGER, 1997).

\section{6 Vetores}

Os transmissores naturais do T. cruzi ao homem são os triatomíneos, insetos popularmente conhecidos no Brasil por "barbeiro, chupão, fincão, bicudo"; nos países latino-americanos por "vinchuca ou chinche"; e nos Estados Unidos por "kissing bug e cone-nosed bug. Os gêneros Triatoma, com 64 espécies, Panstrongylus, com 13 espécies, e Rhodnius, com11 espécies, são os de maior interesse por incluírem as espécies vetoras do $T$. cruzi. Do ponto de vista epidemiológico destacam-se como as mais importantes as seguintes espécies: Triatoma infestans, Panstrongylus megistus e Rhodnius prolixus (CASTRO et al, 1994).

A espécie responsável pelo maior número de casos de infecção humana é o Triatoma infestans, por encontrar-se estritamente adaptada ao domicílio humano, desenvolver grandes colônias com altos índices de infecção e apresentar ampla distribuição geográfica nos países sul-americanos. Admite-se que seja originária dos países andinos e tenha sido introduzida no Brasil através da Argentina e do Uruguai (CASTRO et al, 1994).

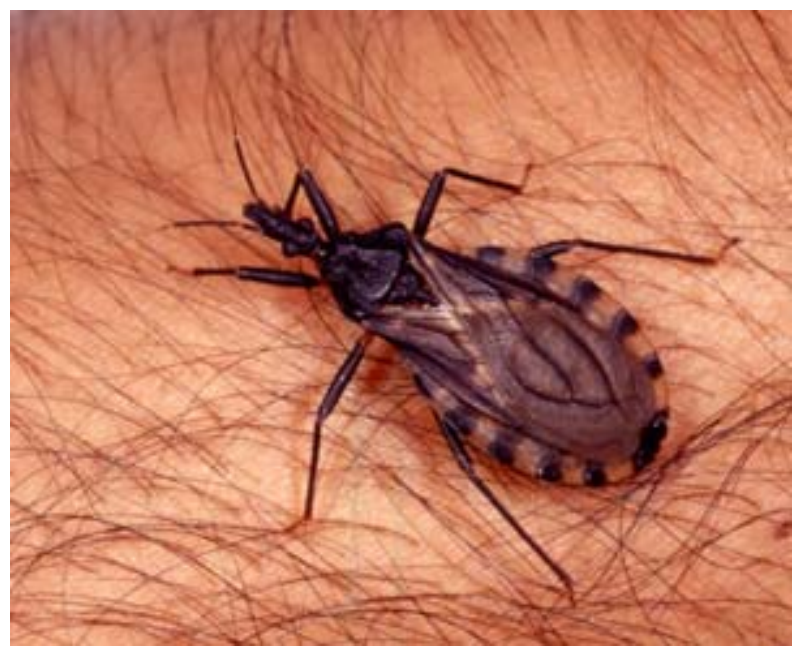

FIGURA 3: Triatoma infestans, triatomíneo hematófago, hospedeiro intermediário da doença de Chagas. WHO - World Health Organization, Geneve, 2003. 
O Panstrongylus megistus é também um vetor importante, sendo encontrado no Brasil, Argentina, Paraguai e Bolívia. É o principal transmissor em algumas áreas dos Estados de Minas Gerais, Goiás e Bahia (CASTRO et al, 1994).

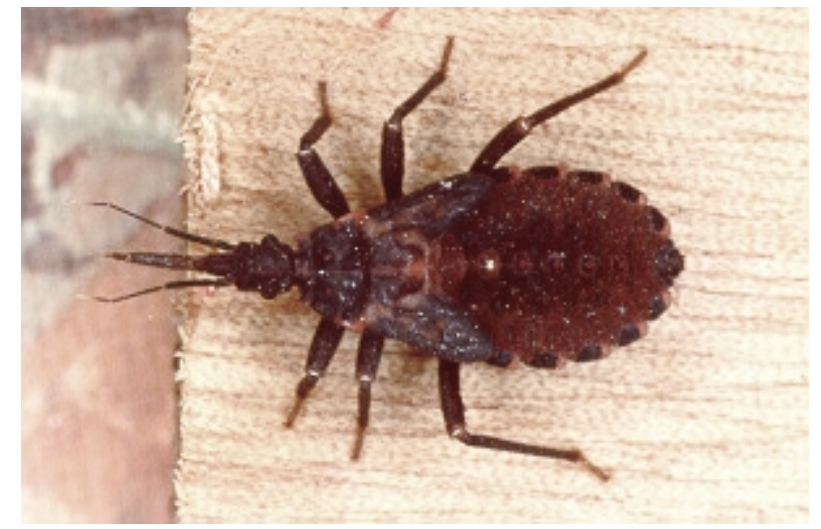

FIGURA 4: Panstrongylus megistus, triatomíneo hematófago, hospedeiro intermediário da doença de Chagas. WHO - World Health Organization, Geneve, 2003.

O Rhodnius prolixus é o principal vetor na Venezuela, Colômbia e países da América Central. Apesar de sinantrópico, pode desenvolver-se em palmeiras e outras árvores, de onde migra para as casas. Sua presença no Brasil já foi assinalada nos Estados do Amazonas, Maranhão e Minas Gerais (CASTRO et al, 1994).

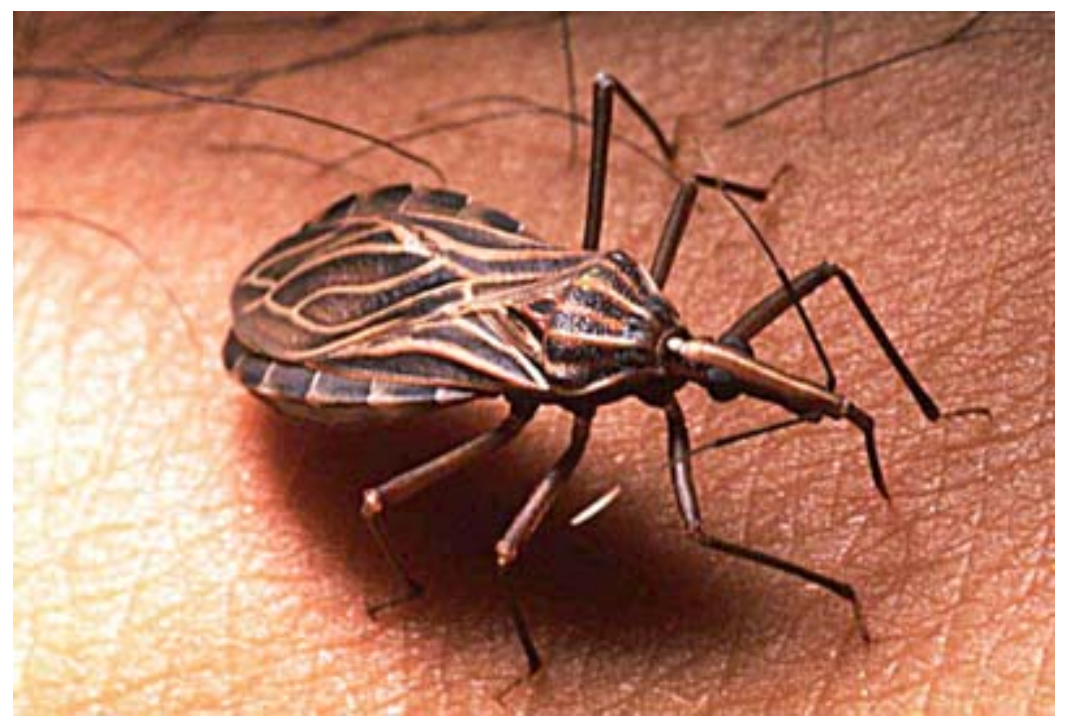

FIGURA 5: Rhodnius prolixus, triatomíneo hematófago, hospedeiro intermediário da doença de Chagas. WHO - World Health Organization, Geneve, 2003. 
A biologia dos triatomíneos difere com as espécies e as condições climáticas ambientais. Para o seu desenvolvimento de ovo a adulto, o triatomíneo passa por cinco estádios ninfais e em todos eles necessita de sangue para alcançar o estádio seguinte. A ovoposição da fêmea, normalmente tem início dois a três dias após o acasalamento de insetos adultos e continua durante toda a vida da fêmea, mesmo sem a presença do macho. Cada fêmea põe cerca de 650 ovos durante sua vida, $88 \%$ dos quais são férteis. Das larvas que se desenvolvem, $61 \%$ chegam ao estádio alado. Os triatomíneos têm grande resistência ao jejum e para o seu desenvolvimento normal são suficientes dois a quatro repastos por mês. Aparentemente os triatomíneos suportam o parasitismo pelo $T$. cruzi sem sofrer conseqüências danosas ao seu ciclo vital (CASTRO et al, 1994).

Este parasito pode infectar cerca de 90 espécies de organismos invertebrados e 100 espécies mamíferos, distribuídos em várias ordens e presentes em muitos países (TEIXEIRA, 1987). Esta ampla variedade de animais constitui importante reservatório natural, propiciando o progresso da doença nas Américas (PASSOS, 2003).

\section{7 Animais Reservatórios}

São assim chamados os animais que apresentam infecção natural pelo T.cruzi. Chagas descobriu em 1909 a infecção natural em gatos e, em 1912, no tatu, identificando desse modo um reservatório doméstico e outro silvestre. A partir de então, o número de animais encontrados naturalmente infectados pelo $T$. cruzi tem aumentado sem cessar (CASTRO et al, 1994).

Os animais reservatórios mais importantes são os marsupiais (gambás), roedores (ratos, peãs, cobaias etc.), quirópteros (morcegos), primatas (macacos), carnívoros (cães, gatos, quatis). Entre os sinantrópicos destacam-se o cão e o gato. Em zonas endêmicas os índices de infecção natural dos cães superam, muitas vezes, os do próprio homem (CASTRO et al, 1994). O T. cruzi apresenta duplo ciclo nos gambás, sendo um ciclo próprio dos vertebrados e outro semelhante ao que se passa nos triatomíneos. Este último ciclo ocorre nas glândulas anais, que funcionam 
como verdadeiros reservatórios de formas metacíclicas infectantes, as quais são continuamente eliminadas para o exterior.

As aves, os répteis e os batráquios são refratários à infecção pelo $T$. cruzi. $O$ sangue destes animais possui atividade lítica mediada pelo complemento contra o $T$. cruzi, o que explica a sua resistência natural à infecção. Por esta razão, as espécies que colonizam os galinheiros do peridomicílio, como o Triatoma sórdida, apresentam baixo índice de infecção (CASTRO et al, 1994).

\section{8 Genética de Camundongos}

Junto ao progresso da genética humana, criou-se a genética de camundongos ou o estudo de modelos animais de doenças humanas. Tais modelos ajudam na compreensão da patogenicidade de várias doenças e, em muitos casos, são usados para testar a eficiência e a ausência de efeitos colaterais de uma terapia gênica que busca a compreensão ou a substituição da função do gene defeituoso no homem (GODARD \& GUENET, 1999).

Os roedores de laboratório suportam relativamente bem um regime de cruzamentos totalmente consangüíneo. Nos ratos e camundongos, podemos fazer acasalamentos entre irmãos durante várias gerações, obtendo assim, populações de animais muito homogêneas do ponto de vista genético. Essas populações são denominadas linhagens consangüíneas e elas são muito estáveis e geneticamente padronizadas: elas têm formas alélicas homozigóticas para todos os loci do genoma e; o conjunto de alelos que compõe o genoma é distribuído de forma aleatória (GODARD \& GUENET, 1999).

Dessa forma fica claro que toda comparação feita entre camundongos provenientes de linhagens diferentes revelará diferenças genéticas. Para termos acesso a tais diferenças devemos cruzar as diferentes linhagens e analisar a transmissão genética de um ou mais caracteres genéticos de uma geração a outra (GODARD \& GUENET, 1999).

Algumas dessas linhagens consangüíneas desenvolvem doenças e são consideradas modelos animais para a medicina. Por outro lado, as linhagens 
consangüíneas podem apresentar diferenças quanto às reações a agentes infecciosos; enquanto algumas linhagens são dizimadas pela infecção de um agente patogênico, outras são resistentes. Nesse caso, a noção de modelo animal é um pouco mais complicada, pois os mecanismos envolvidos no determinismo genético das diferenças de sensibilidade às infecções não são integralmente transponíveis de uma espécie para outra. Esta é uma área de estudo que só tende a se desenvolver e as estratégias serão cada vez mais generalizadas, mas sempre buscarão o mesmo resultado, que deverá ser o desenvolvimento de vacinas ou de tratamentos para as doenças infecto-contagiosas (GODARD \& GUENET, 1999).

As linhagens consangüíneas de camundongos de laboratório derivam todas de um pequeno número de genitores. Isto, do ponto de vista genético, significa que não existe muita diferença entre os genomas. Por exemplo, todas essas linhagens possuem a mesma molécula de DNA mitocondrial (herdado da mãe) e o mesmo cromossomo $Y$ (herdado do pai). Tal homogeneidade é um fator positivo para alguns estudos (GODARD \& GUENET, 1999).

As mutações fazem surgir uma segunda forma alélica permitindo, deste modo, a identificação dos genes responsáveis. Assim que elas são transmitidas às gerações seguintes, freqüentemente os seus efeitos são deletérios ou patológicos e podem, neste momento, servirem de modelo para algumas doenças hereditárias humanas ou se tornam, simplesmente, um utensílio para a ciência. As mutações permitem identificar um gene por meio de um fenótipo patológico ou anormal. Isso quer dizer que é possível clonar um gene identificado unicamente por um alelo mutado, do qual o fenótipo é, a priori, interessante, e isolar um gene cuja função é importante (GODARD \& GUENET, 1999)

Pesquisadores em 1989 conseguiram substituir in vitro, ou seja, dentro das células embrionárias em cultura, uma seqüência de DNA normal por uma seqüência homóloga mutada. Esta técnica, chamada de "recombinação" permite, em teoria, inativar qualquer gene, desde que sua seqüência genômica seja conhecida. Tecnicamente pode-se inativar, de maneira sistemática, todos os genes dos quais a seqüência seja conhecida, mas não a sua função, para então poder conhecer seus efeitos sobre o embrião ou adulto. Por meio desse método já foram produzidos 
muitos modelos animais de doenças humanas. Até o presente momento, esta técnica tem sido usada unicamente nos camundongos, pois só nessa espécie é que existem as células E.S. (Embryonic Stem cells) e, na maior parte do tempo, elas só permitem a produção de um alelo nulo de um determinado gene (GODARD \& GUENET, 1999).

Estudos realizados em camundongos normais, mutantes e knock-out, com o propósito de identificar componentes do sistema imune, envolvidos com o controle da infecção, demonstraram que os mecanismos relacionados à resistência e à susceptibilidade são complexos que sofrem influência do genoma dos animais. Tal influência ocorre tanto com relação aos elementos conhecidos da imunidade inata, celular e humoral, como de aspectos ainda não esclarecidos de controle da infecção (MARTINS et al, 1999).

Entretanto a resposta inata por si só não pode responder pelo controle da infecção (NETO, 1999). Em 1991 Nabors \& Tarleton, investigando a participação de outras células e moléculas envolvidas na resposta imune da infecção Chagásica, observaram que linfócitos $T$, extraídos de linhagens de camundongos resistentes e susceptíveis à infecção pelo $T$. cruzi, produziam maior quantidade de IFN- $\gamma$, indicativo de uma resposta imune complexa.

Demonstrou-se posteriormente que a manutenção de resposta imune, com altos níveis de produção de INF- $\gamma$ durante a fase crônica da infecção, pode favorecer a cura ou influenciar o desenvolvimento da forma cardíaca da doença (OLIVEIRA et al,1998).

Além disso, moléculas como citocinas, que atuam como amplificadores da resposta imune, são extensamente estudadas e relacionadas à resistência ao parasito, sem que possam, contudo, serem consideradas isoladamente, demonstrando pertencerem a um mecanismo integrado de resposta, que conduz à sobrevivência do hospedeiro. Os aspectos imunológicos relatados por vários autores reforçam a hipótese de que, a doença de Chagas é multifatorial, de expressão variável e dependente de genes do hospedeiro para a modulação da resposta imune, com vista a controlar a infecção (PASSOS, 2003).

É aceito que a infecção chagásica desencadeia uma série de respostas imunológicas, que convergem para reações similares àquelas encontradas em 
doenças auto-imunes, as quais, além de serem influenciadas por eventos bioquímicos, como mimetismo molecular, dependem de um mecanismo genético complexo, ainda não elucidado (VYSE \& TODD,1996).

\section{9 Aspectos Imunológicos}

Assim como a mente humana permite que um indivíduo desenvolva um conceito do eu intelectual, o sistema imune provê um conceito do eu biológico. A função do sistema imune é defender o corpo contra invasores. Os microrganismos, as células cancerosas e os tecidos ou órgãos transplantados são interpretados pelo sistema imune como algo contra o qual o corpo deve ser defendido. Embora o sistema imune seja complexo, a sua estratégia básica é simples: reconhecer o inimigo, mobilizar forças e atacar (SHARP, 2004).

O sistema imune mantém seu próprio sistema de circulação (os vasos linfáticos), o qual permeia todos os órgãos do corpo, excetuando-se o cérebro. Os vasos linfáticos contêm um líquido pálido e espesso (linfa) formado por um líquido carregado de gordura e de leucócitos. Ao longo dos vasos linfáticos existem áreas especiais (linfonodos, tonsilas, medula óssea, baço, fígado, pulmões e intestinos) nas quais é possível recrutar, mobilizar e deslocar linfócitos até zonas específicas como parte da resposta imune. O desenho engenhoso desse sistema assegura a disponibilidade imediata e a produção rápida de uma resposta imune onde quer que seja necessário (SHARP, 2004).

O sistema imune é composto por células e substâncias solúveis. Macrófagos, neutrófilos e linfócitos são todos tipos de leucócitos, principais células do sistema imune. As principais substâncias solúveis são os anticorpos, as proteínas do complemento e as citocinas, que não estão contidas em células, mas dissolvidas em um líquido (plasma, por exemplo). Algumas substâncias solúveis funcionam como mensageiros para atrair e ativar outras células. O complexo de histocompatibilidade

principal é a base do sistema imune e ajuda na identificação do que é próprio do organismo e do que não o é (SHARP, 2004). 


\section{9.1 Leucócitos}

\section{9. 1. 1 Macrófagos}

Os macrófagos são leucócitos grandes que fagocitam microrganismos, antígenos e outras substâncias. O citoplasma dos macrófagos contém grânulos (ou pacotes) que consistem em várias substâncias químicas e enzimas que são envolvidas por uma membrana. Essas enzimas e substâncias químicas permitem ao macrófago digerir o microrganismo ingerido, geralmente destruindo-o. Os macrófagos não são encontrados no sangue. Ao invés disso, eles localizam-se estrategicamente onde os órgãos do corpo entram em contato com a corrente sangüínea ou com o mundo exterior. Por exemplo, os macrófagos são encontrados onde os pulmões recebem o ar do exterior e onde as células do fígado conectam-se com os vasos sangüíneos. Células similares presentes no sangue são denominadas monócitos (SHARP, 2004).

\section{9. 1. 2 Neutrófilos}

Como os macrófagos, os neutrófilos são grandes leucócitos que fagocitam microrganismos e outros antígenos e que possuem grânulos contendo enzimas para destruir antígenos fagocitados. No entanto, ao contrário dos macrófagos, os neutrófilos circulam no sangue; eles necessitam de um estímulo específico para sair do sangue e entrar nos tecidos. Os macrófagos e os neutrófilos freqüentemente atuam em conjunto. Os macrófagos iniciam uma resposta imune e enviam sinais para mobilizar os neutrófilos para que estes se juntem a eles na área com problema. Quando os neutrófilos chegam, eles destroem os invasores, digerindo-os. O acúmulo de neutrófilos e a destruição e a digestão dos microrganismos acarretam a formação de secreção purulenta. (SHARP, 2004). 


\section{9. 1. 3 Linfócitos}

Os linfócitos, as principais células do sistema linfático, são relativamente pequenos em comparação com os macrófagos e os neutrófilos. Ao contrário dos os neutrófilos, os quais vivem de 7 a 10 dias, os linfócitos podem viver durante anos ou mesmo décadas. A maioria dos linfócitos é enquadrada em três categorias principais:

- Os linfócitos B são derivados de uma célula-tronco da medula óssea e amadurecem até transformarem-se em plasmócitos, os quais secretam anticorpos (SHARP, 2004).

- Os linfócitos T são formados quando as células-tronco migram da medula óssea até a glândula timo, onde eles dividem-se e amadurecem. Os linfócitos T aprendem como diferenciar o que é próprio do organismo do que não o é no timo. Os linfócitos $T$ maduros deixam o timo e entram no sistema linfático, onde eles atuam como parte do sistema imune de vigilância (SHARP, 2004).

Existem dois tipos de células $T$ efetoras, os linfócitos $T$ auxiliadores (helper) (Th) e os linfócitos T citotóxico (Tc), que carregam em suas superfícies moléculas de CD4 ou CD8, respectivamente. As células Th CD4+ são orquestrantes da resposta imune, reconhecendo antígenos externos, e ativando outros caminhos da resposta imune mediada por células a fim de erradicar o patógeno. As células T CD8 lisam as células-alvo que apresentam fragmentos antigênicos, ligados a moléculas $\mathrm{MHC}$ de classe I (DELVES e ROITT, 2000).

As células Th CD4 reconhecem antígenos ligados as moléculas MHC de classe II. As células Th CD4 apresentam dois subtipos, células Th1 e células Th2, que surgem de um precursor Th0 e são diferenciadas de acordo com as citocinas que produzem, pois morfologicamente são indistinguíveis. Contudo, a resposta gerada e muito diferente. As células Th1 produzem a interleucina 2, que induz a proliferação das células $T$, incluindo aquelas $C D 4+$ da resposta autócrina. A interleucina 2 também estimula a divisão das células T CD8+ e sua toxicidade. Outra citocina produzida pelas células Th1 é o interferon $\gamma$, responsável pela ativação de macrófagos que eliminam patógenos intracelulares como micobacterias, fungos, protozoários e ainda, induzem a citotoxicidade das células natural killer. Portanto, as 
citocinas produzidas pelas células Th1, são as principais responsáveis pela indução da resposta inflamatória. (PARKIN e COHEN, 2001)

Existe um feedback positivo que se refere ao fato do interferon $\gamma$ estimular as células Th0 a se transformarem em células Th1 e, ao mesmo tempo, inibindo a diferenciação de células Th2. A resposta Th1 e essencial no controle da replicação de patógenos intracelulares, mas possivelmente contribui na patogênese de doenças autoimunes como a artrite reumatóide e a esclerose múltipla. As células Th2, por sua vez, produzem interleucinas 4, 5, 6 e 10, que favorecem a produção de anticorpos. A interleucina 4 induz as células $B$ a produzir $\operatorname{lgE}$ e a interleucina 5 promove 0 crescimento de eosinófilos. A interleucina 4 também promove um feedback positivo ao favorecer a indução da resposta Th2 e suprimir a diferenciação de células Th1. Assim, a resposta Th2 esta associada com doenças alérgicas. (DELVES e ROITT, 2000; PARKIN e COHEN, 2001)

- As células natural killer, discretamente maiores que os linfócitos T e B, são assim denominadas por matarem determinados microrganismos e células cancerosas. O "natural" de seu nome indica que elas estão prontas para destruir uma variedade de células-alvo assim que são formadas, em vez de exigirem a maturação e o processo educativo que os linfócitos B e $T$ necessitam. As células assassinas naturais também produzem algumas citocinas, substâncias mensageiras que regulam algumas das funções dos linfócitos $T$, dos linfócitos $B$ e dos macrófagos (SHARP, 2004).

\section{9.2 Substâncias Solúveis}

\section{9. 2. 1 Anticorpos}

Quando estimulados por um antígeno, os linfócitos B amadurecem até se transformarem em células produtoras de anticorpos. Anticorpos são proteínas que interagem com o antígeno que inicialmente estimula os linfócitos B. Os anticorpos também são denominados imunoglobulinas. Cada molécula de anticorpo possui uma parte única que se liga a um antígeno específico e uma parte cuja estrutura 
determina a classe do anticorpo. Existem cinco classes de anticorpos: IgM, IgG, IgA, IgE e IgD (SHARP, 2004).

- A IgM é o anticorpo produzido após a exposição inicial a um antígeno. Quando uma criança recebe sua primeira vacina contra o tétano, os anticorpos antitétano da classe IgM são produzidos 10 a 14 dias mais tarde (resposta de anticorpos primária). A lgM é abundante no sangue, mas normalmente não se encontra presente nos órgãos ou nos tecidos (SHARP, 2004).

- A lgG, o tipo de anticorpo mais prevalente, é produzido após a exposição subseqüente a um antígeno. Por exemplo, após uma segunda vacina antitetânica (reforço), a criança produz anticorpos da classe $\operatorname{lgG}$ em 5 a 7 dias. A resposta de anticorpos secundária é mais rápida e mais abundante que a resposta primária. $A$ IgG está presente tanto no sangue como nos tecidos. Trata-se do único anticorpo que é transferido através da placenta, da mãe para o feto. A lgG materna protege o feto e o recém nascido até que o sistema imune do bebê possa produzir seus próprios anticorpos (SHARP, 2004).

- A IgA é o anticorpo que tem um papel importante na defesa do corpo contra a invasão de microrganismos através das superfícies revestidas por membrana mucosa (p.ex., nariz, olhos, pulmões e intestinos). A IgA é encontrada no sangue e em secreções como as do trato gastrintestinal, do nariz, dos olhos, dos pulmões e no leite materno (SHARP, 2004).

- A IgE é o anticorpo que causa reações alérgicas agudas (imediatas). Neste aspecto, a lgE é a única classe de anticorpo que aparentemente faz mais mal que bem. Contudo, a IgE pode ser importante no combate às infecções parasitárias, como a oncocercose e a esquistossomose, as quais são comuns nos países em desenvolvimento (SHARP, 2004).

- A IgD é um anticorpo presente em quantidades muito pequenas no sangue circulante. A sua função não é totalmente conhecida (SHARP, 2004). 


\section{9. 2. 2 Sistema do Complemento}

O sistema do complemento compreende mais de 18 proteínas. Essas proteínas atuam em cascata, com uma proteína ativando a proteína seguinte. $\mathrm{O}$ sistema do complemento pode ser ativado por duas vias distintas. Uma via, denominada via alternativa, é ativada por certos produtos microbianos ou antígenos. A outra via, denominada via clássica, é ativada por anticorpos específicos ligados a seus antígenos (complexos imunes). O sistema do complemento atua para destruir substâncias estranhas, seja diretamente ou em conjunto com outros componentes do sistema imune (SHARP, 2004).

\section{9. 2. 3 Citocinas}

As citocinas atuam como mensageiros do sistema imune. Essas substâncias são secretadas por células do sistema imune em resposta à estimulação. As citocinas amplificam (ou ajudam) alguns aspectos do sistema imune e inibem (ou suprimem) outros. Muitas citocinas já foram identificadas e a lista continua aumentando. Algumas citocinas podem ser injetadas como tratamento de certas doenças. Por exemplo, o interferon alfa é eficaz no tratamento de certos cânceres, como a leucemia das células pilosas. Outra citocina, o interferon beta, pode ser útil no tratamento da esclerose múltipla. Uma terceira citocina, a interleucina-2, pode ser benéfica no tratamento do melanoma maligno e do câncer de rim, embora seu uso produza efeitos adversos. Uma outra citocina, o fator estimulador de colônias de granulócitos, o qual estimula a produção de neutrófilos, pode ser administrada em pacientes de câncer com contagens baixas de neutrófilos causadas pela quimioterapia (SHARP, 2004).

Diante da importância de todos os aspectos acima descritos e dos avanços biotecnológicos que presenciamos constantemente, vimos relevância em estudar a resposta imunológica de diferentes linhagens de camundongos frente à infecção por T. cruzi. 


\section{3 - OBJETIVO GERAL}

Avaliar o padrão de resposta de imunoglobulinas em linhagens de camundongos resistentes e susceptíveis à infecção por $T$. cruzi.

\section{Especificamente:}

- Avaliar o padrão de resposta de imunoglobulinas de camundongos da linhagem C57BL/6.

- Avaliar o padrão de resposta de imunoglobulinas de camundongos da linhagem A/J.

- Avaliar o padrão de resposta de imunoglobulinas de camundongos oriundos do acasalamento entre as linhagens susceptíveis e resistentes.

- Avaliar o padrão de resposta de imunoglobulinas de camundongos das linhagens recombinantes isogênicas derivadas de parentais resistentes e susceptíveis. 


\section{4 - MATERIAIS E MÉTODOS}

\subsection{Materiais}

Serão descritos a seguir o parasito, os animais e os reagentes que foram utilizados neste experimento para que o objetivo proposto fosse alcançado.

\section{1. 1 O Parasito}

Foram utilizadas formas de cultivo da cepa $Y$ de $T$. cruzi para a purificação do antígeno empregado nos ensaios imunoenzimáticos (ELISA). Esta cepa foi cedida pela Dra. Eufrosina S. Umezawa do Laboratório de Protozoologia do IMT - FMUSP SP.

Foram também utilizadas formas sangüícolas da cepa $\mathrm{Y}$ de $T$. cruzi, provenientes do Departamento de Imunologia do Instituto de Biologia da UNICAMP, cedidas pelo Dr. Luiz Augusto Corrêa Passos, para os testes de infecção.

\subsection{Animais}

Para a realização dos experimentos, foram utilizados animais das linhagens A/J, C57BL/6, B6AF1, BXA1, BXA2, BXA4 e BXA7 oriundos de Colônias do CEMIB/UNICAMP, cuja integridade sanitária e genética foi preservada pela manutenção dos modelos em unidades isoladoras flexíveis.

\section{1. 3 Reagentes}

Todos os reagentes utilizados foram de qualidade pró-análise e a água purificada em sistema Milli-Q. 


\section{2 Métodos}

4. 2. 1 Manutenção do T. cruzi em Cultivo

As formas de T. cruzi foram cultivadas em meio LIT (Liver Infusion Tryptose) com S.F.B. (soro fetal bovino) a $10 \%$ sem antibiótico e incubadas à temperatura de $26^{\circ} \mathrm{C}$ em estufa tipo D.B.O (Demanda Bioquímica de Oxigênio). Procedeu-se o repique das culturas a cada 7 dias.

\section{2. 1.1 Obtenção do Antígeno de T. cruzi}

A obtenção do antígeno de $T$. cruzi foi feita a partir de formas da cepa $Y$ mantidas em cultivo no meio LIT com $10 \%$ de S.F.B. a $26^{\circ} \mathrm{C}$. Os parasitos foram centrifugados a $10000 \mathrm{~g}$ por 10 minutos a $10^{\circ} \mathrm{C}$. O sedimento foi ressuspenso e lavado por duas vezes em PBS pH 7,2 estéril e estocado em freezer a $-70^{\circ} \mathrm{C}$. Ao sedimento em tubo cônico de PVC adicionou-se $4 \mathrm{ml}$ de água destilada e a suspensão foi submetida ao ultra-som (THORNTON-INPEC ${ }^{\circledR}$ ) a 40 ciclos por períodos de 30 segundos, em banho de gelo. Certificada a lise completa dos parasitos por meio de verificação, em lâmina e lamínula, no microscópio óptico, adicionou-se ao material $4 \mathrm{ml}$ de $\mathrm{NaOH} 0,3 \mathrm{M}$ e centrifugou-se a $10000 \mathrm{~g}$ por 30 minutos a $4^{\circ} \mathrm{C}$. Após dosagem de proteínas, pelo método de Bradford, o sobrenadante foi armazenado, em alíquotas, $\mathrm{a}-70^{\circ} \mathrm{C}$.

\section{2. 1. 2 Teste de Infecção com Diferentes Concentrações de T. cruzi}

Animais das linhagens C57BL/6 e A/J foram infectados com diferentes concentrações de parasito, a fim de determinar uma dose capaz de diferenciar uma linhagem susceptível e outra resistente à infecção por $T$. cruzi.

O ensaio foi realizado inoculando-se grupos de animais, de ambas as linhagens, com $10^{1}, 10^{2}, 10^{3}, 10^{4}$ e $10^{5}$ formas de tripomastigotas. (PASSOS et al, 2002). 
Com base nos resultados obtidos, durante todos os demais experimentos a linhagem $\mathrm{A} / \mathrm{J}$ foi infectada com concentrações de $10^{1}$ e $10^{2}$ tripomastigotas e a linhagem C57BL/6 com concentrações de $10^{3}$ e $10^{4}$ tripomastigotas.

\section{2. 1. 3 T. cruzi Sangüícolas para os Testes de Infecção}

Sangue contendo formas tripomastigotas de $T$. cruzi em diferentes concentrações de parasitos recém colhidos dos animais infectados foi cedido pelo Dr. Luiz Augusto Corrêa Passos do CEMIB/UNICAMP.

\section{2. 2 Manutenção dos Animais}

Animais das linhagens C57BL/6 e $\mathrm{A} / \mathrm{J}$ foram alojados e mantidos em condições SPF durante todos os experimentos. Os animais receberam alimentação e água a vontade.

4. 2. 2.1 Infecção Experimental das Linhagens Parentais Originais de Fenótipos Resistentes e Susceptíveis com a Cepa Y de T. cruzi.

Foram selecionados machos e fêmeas das linhagens C57BL/6 e A/J com 10 a 12 semanas de idade, as quais apresentam respectivamente o fenótipo resistente e susceptível após infecção com a cepa $Y$ de $T$. cruzi.

Os testes foram realizados com concentrações de $10^{1}$ e $10^{2}$ tripomastigotas por animal da linhagem $\mathrm{A} / \mathrm{J}$ e com concentrações de $10^{3}$ e $10^{4}$ tripomastigotas por animal da linhagem C57BL/6, inoculadas por via intra-peritoneal.

A constatação da infecção foi feita entre o $7^{\circ}$ e $\circ 14^{\circ}$ dia após o inóculo e a mortalidade foi acompanhada diariamente por um período superior a trinta dias (PASSOS, 2003). 


\section{2. 2. 2 Obtenção e Infecção de Híbridos B6AF1}

Animais oriundos das linhagens resistente e susceptível foram acasalados para a obtenção de híbridos F1. Os casais foram constituídos de fêmeas da linhagem C57BL/6 e machos da linhagem A/J. A progênie F1 obtida foi acompanhada até alcançar a idade de 8 a 12 semanas, quando foi inoculada uma concentração de $10^{4}$ tripomastigotas por via intra-peritoneal. A constatação da infecção e a mortalidade seguiram os mesmos procedimentos descritos por Passos (2003).

\section{2. 2. 3 Obtenção dos Animais Recombinantes Isogênicos}

As linhagens recombinantes isogênicas foram importadas, acasaladas e mantidas no CEMIB/UNICAMP. Posteriormente elas foram trazidas para o IPEN onde foram mantidas no biotério da unidade em condições SPF. Ao alcançar a idade de 10 a 12 semanas foram infectadas com concentração de $10^{4}$ tripomastigotas por via intra-peritoneal. A constatação da infecção e a mortalidade seguiram os mesmos procedimentos descritos por Passos (2003).

4. 2. 2. 4 Obtenção de Soro das Linhagens Parentais Originais, dos Híbridos B6AF1 e das Linhagens Recombinantes Isogênicas

Após constatação da parasitemia, foram realizadas sangrias pelo plexo retroorbital a cada sete dias, onde o sangue foi mantido a $37^{\circ} \mathrm{C}$ por cerca de 45 minutos para a retração de coágulo. Com a retirada dos coágulos procedeu-se a centrifugação para a separação do soro e dos elementos celulares $(800 \mathrm{~g}$ por 15 minutos). Após centrifugação o sobrenadante foi retirado com o auxílio de uma pipeta Pasteur. O soro obtido foi acondicionado em tubos estéreis, bem fechados e mantidos em freezer. 


\section{2. 3 Ensaio Imunoenzimático (ELISA)}

A presença de anticorpos específicos pode ser detectada pelo emprego de diferentes ensaios. Alguns medem a ligação direta do anticorpo ao seu antígeno, sendo estes ensaios baseados em interações primárias, como é o caso do ELISA (Enzyme Linked Immuno Sorbent Assay) (ALVES, 2004).

O ELISA foi feito em micro placas, às quais foi adsorvida o antígeno em tampão carbonato/bicarbonato $\mathrm{pH} 9,6$, "over night" a $4^{\circ} \mathrm{C}$. Após lavagens com PBS contendo $0,5 \%$ de Tween 20 , eventuais sítios de ligação inespecíficos foram bloqueados com solução de bloqueio (PBST + Leite $3 \mathrm{~g} / 100 \mathrm{ml}$ ) por 1 hora, a $37^{\circ} \mathrm{C}$. Após novas lavagens, o soro diluído a 1/50,1/100 e 1/200, foi adicionado às placas e incubado a $37^{\circ} \mathrm{C}$. Após um novo ciclo de lavagem, os conjugados de peroxidase com IgG anti-IgG total,anti-lgG1 IgG2a ou IgG2b de camundongo, diluídos a 1/5000 (IgG total) e 1/ 10000 (IgG1, IgG2a e IgG2b) em solução de bloqueio, foram adicionados aos poços predeterminados e incubados por 1 hora a $37^{\circ} \mathrm{C}$. Após as lavagens finais, o substrato cromógeno O-phenylenediamine-OPD $(0,5 \mathrm{mg} / \mathrm{ml})$ diluído em tampão citrato de sódio/ácido cítrico (0,05M; pH 5,0) e $\mathrm{H}_{2} \mathrm{O}_{2}(30 \%)$, foi adicionado à placa e incubado por 20 minutos em câmara escura. A reação foi interrompida pela adição de ácido cítrico $0,2 \mathrm{M}$. A absorvância foi verificada em leitor de microplacas, no comprimento de ondas de 450nm.

\section{2. 4 Análise Estatística}

Os dados freqüenciais foram comparados pelo teste Chi-quadrado. 


\section{5 - RESULTADOS}

\section{1 Infecção Experimental com T. cruzi das Linhagens C57BL/6 e A/J}

O primeiro grupo experimental foi formado de animais das linhagens C57BL/6 e $A / J$, os quais foram infectados com diferentes concentrações de tripomastigotas, inoculados via intra-peritoneal.

Em função das concentrações empregadas, todos os animais inoculados foram investigados no intervalo compreendido entre o $7^{\circ}$ e $14^{\circ}$ dia após a infecção, com o propósito de se assegurar a presença do parasita.

O padrão de resultados encontrados em ambas as linhagens obedeceu ao esperado para animais isogênicos, onde os indivíduos que sobreviveram mais que 30 dias foram considerados resistentes.

A tabela 1 resume os resultados encontrados com a administração de diferentes concentrações de $T$. cruzi nas linhagens C57BL/6 e A/J.

Os resultados confirmam a existência de uma diferença significativa entre as duas linhagens, frente à administração de diferentes concentrações do parasita. Os animais da linhagem A/J foram considerados susceptíveis e os animais da C57BL/6 foram considerados resistentes à infecção por $T$. cruzi.

TABELA 1 - Infecção experimental dos animais das linhagens C57BL/6 e A/J, após a inoculação de diferentes concentrações de $T$. cruzi.

\begin{tabular}{|c|c|c|c|}
\hline Linhagem & Concentração & Infectados/Resistentes & \% de Resistência \\
\hline C57BL/6 & $10^{3}$ & $10 / 10$ & 100 \\
& $10^{4}$ & $10 / 8$ & 80 \\
\hline A/J & $10^{1}$ & $10 / 1$ & 10 \\
& $10^{2}$ & $10 / 0$ & 0 \\
\hline
\end{tabular}

A diferença entre as duas linhagens quanto à resistência foram altamente significativas. $O$ valor do $X^{2}$ para estes resultados foi: $X^{2}=16,36 ; p=5,2 \times 10^{-5}$. 


\section{2 Infecção Experimental com T. cruzi dos Híbridos B6AF1}

O segundo grupo experimental foi formado com animais híbridos F1, derivados de acasalamentos realizados entre as linhagens C57BL/6 e A/J, respectivamente de fenótipo resistente e susceptível.

Os indivíduos deste grupo são idênticos quanto à sua composição genética, possibilitando um padrão homogêneo de resposta após a inoculação com o $T$. cruzi.

Após a administração das concentrações de $10^{4}$ e $10^{5}$ tripomastigotas, os animais do grupo foram examinados no período entre $\circ 7^{\circ}$ e $\circ 14^{\circ}$ dias para a verificação da infecção.

Os resultados obtidos com este grupo experimental estão representados na tabela 2.

TABELA 2 - Comparação das linhagens susceptível, resistente e híbrida após inoculo de T. cruzi.

\begin{tabular}{|c|c|c|c|c|}
\hline & Fenótipo & Concentração & Infectados/Resistentes & $\begin{array}{c}\text { (\%) de } \\
\text { Resistência }\end{array}$ \\
\hline A/J & Susceptível & $10^{4}$ & $10 / 0$ & 0 \\
C57BL/6 & Resistente & $10^{4}$ & $10 / 8$ & 80 \\
\hline \multirow{2}{*}{ B6AF1 } & & $10^{4}$ & $10 / 9$ & 90 \\
& Híbrido & $10^{5}$ & $10 / 3$ & 30 \\
\hline
\end{tabular}

A relação entre a linhagem resistente original (C57BL/6) e híbrida (B6AF1) revelou não haver diferença estatística entre ambas quando analisadas com a concentração de $10^{4}$ tripomastigotas. $O$ valor do $X^{2}$ para estes resultados foi: $X^{2}=0,39 ; p=0,53117$.

Os dados encontrados neste grupo experimental revelam que, frente à dose $10^{4}$ tripomastigotas, o comportamento observado nos animais híbridos B6AF1 é similar ao observado na linhagem parental original de fenótipo resistente C57BL/6. A elevada sobrevivência dos indivíduos deste grupo demonstra que a resistência foi transmitida e o fenômeno é de caráter dominante. 


\subsection{Infecção Experimental dos Animais das Linhagens Recombinantes Isogênicas}

O terceiro grupo experimental foi formado com animais das linhagens recombinantes isogênicas $B X A 1, B X A 2$, BXA4 e BXA7, que foram obtidas a partir de misturas ao acaso do genoma de duas linhagens isogênicas parentais, fixadas com o acasalamento entre dois indivíduos $\mathrm{F} 1$, na forma de intercross, por 20 gerações (MELVOLD, 1986).

Após a administração da concentração de $10^{4}$ tripomastigotas, os animais do grupo foram examinados no período entre $\circ 7^{\circ}$ e $\circ 14^{\circ}$ dias para a constatação da infecção.

Foram identificados dois grupos de animais com comportamentos diferentes, quanto à sobrevivência após a inoculação do parasito. No primeiro grupo, formado pelas linhagens BXA1 e BXA7, cerca de $50 \%$ dos indivíduos que receberam a concentração de $10^{4}$ tripomastigotas permaneceram vivos após 30 dias de infecção. Por outro lado, apenas $20 \%$ dos animais das linhagens BXA2 e BXA4 que foram inoculados sobreviveram a esse mesmo período.

Os resultados encontrados com estas populações de alta e baixa sobrevivência estão representados nas Tabelas 3 e 4.

TABELA 3 - Infecção experimental dos animais isogênico recombinantes (BXA1 e BXA7) após inoculo de T. cruzi.

\begin{tabular}{|c|c|c|c|c|}
\hline RIS & Grupo & Concentração & Infectados/Resistentes & $\begin{array}{c}\text { (\%) de } \\
\text { Resistência }\end{array}$ \\
\hline BXA1 & & $10^{4}$ & $26 / 14$ & 54 \\
BXA7 & 1 & $10^{4}$ & $29 / 12$ & 42 \\
\hline Total & & & $55 / 26$ & 48 \\
\hline
\end{tabular}

A comparação entre os dados encontrados para as linhagens BXA1 e BXA7 revelaram comportamento similar entre elas. $O$ valor do $X^{2}$ para estes resultados foi: $X^{2}=0,85 ; p=0,3549$. 
Os resultados obtidos com o grupo de menor sobrevivência também demonstram não haver diferenças significativas entre as linhagens BXA2 e BXA4 quando comparadas entre si.

TABELA 4 - Infecção experimental dos animais isogênicos recombinantes (BXA2 e BXA4) após inoculo de $T$. cruzi.

\begin{tabular}{|c|c|c|c|c|}
\hline RIS & Grupo & Concentração & Infectados/Resistentes & $\begin{array}{c}\text { (\%) de } \\
\text { Resistência }\end{array}$ \\
\hline BXA2 & & $10^{4}$ & $29 / 7$ & 24 \\
BXA4 & II & $10^{4}$ & $39 / 7$ & 18 \\
\hline Total & & & $68 / 14$ & 21 \\
\hline
\end{tabular}

A comparação entre os dados encontrados para as linhagens BXA2 e BXA4 revelaram comportamento similar entre elas. $O$ valor do $X^{2}$ para estes resultados foi: $X^{2}=0,39 ; p=0,5322$.

A comparação entre os dois grupos de animais (BXA1 e BXA2) utilizados na segunda fase dos experimentos para a realização dos ensaios imunoenzimáticos, revelou existir uma diferença significativa entre elas após a inoculação com a concentração de $10^{4}$ tripomastigotas.

TABELA 5 - Comparação das linhagens BXA1 e BXA2 após inoculo de T. cruzi.

\begin{tabular}{|c|c|c|c|}
\hline & Concentração & Infectados/Resistentes & $\begin{array}{c}\text { (\%) de } \\
\text { Resistência }\end{array}$ \\
\hline BXA1 & $10^{4}$ & $26 / 14$ & 54 \\
BXA2 & $10^{4}$ & $29 / 7$ & 24 \\
\hline Total & & $55 / 21$ & 38 \\
\hline
\end{tabular}

A diferença encontrada entre as linhagens BXA1 e BXA2 é significativa. O valor do X2 para estes resultados foi: $X 2=5,13 ; p=0,02366$.

\section{4 Ensaio Imunoenzimático (ELISA)}

No gráfico 1, abaixo representado, pode ser observado que o soro coletado na $6^{\circ}$ sangria dos animais infectados com T. cruzi , apresentou resposta detectável nas três diluições 1:50, 1;100 e 1;200 usadas para a avaliação de anticorpos específicos (lgG Total). 
Esse ensaio imunoenzimático foi realizado com o objetivo de selecionar a melhor diluição para que então fossem realizados os demais testes.

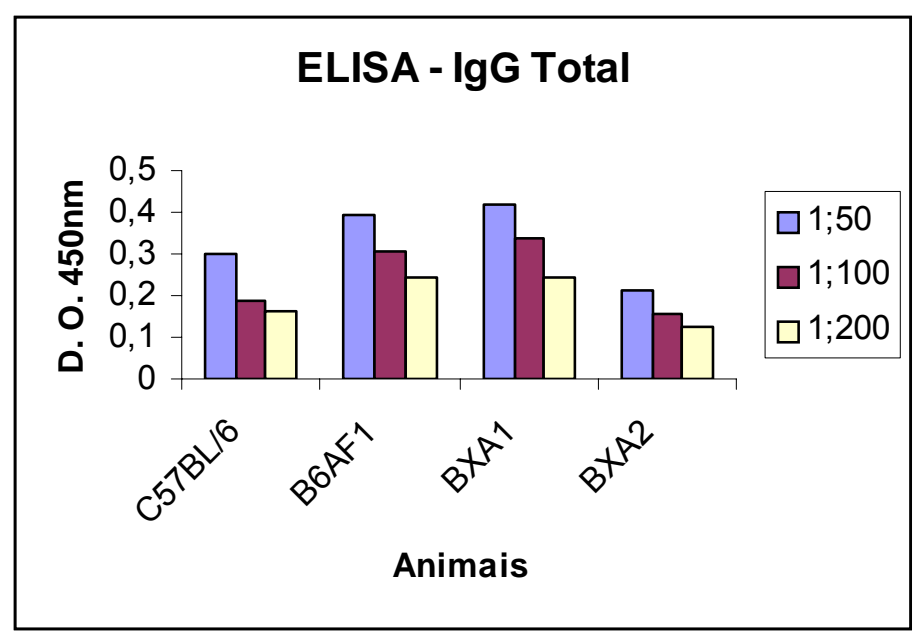

GRÁFICO 1 - Ensaio imunoenzimático para avaliação de anticorpos específicos (IgG Total) com soro proveniente da $6^{\circ}$ sangria com diferentes diluições (1:50, 1:100, 1:200)

A diluição 1;50 foi então escolhida para a realização dos demais testes.

Foram então realizados testes com as sete sangrias obtidas ao longo do experimento para avaliação da produção de anticorpos específicos (IgG Total) com diluição 1:50. Os resultados apresentados nos gráficos $2,3,4,5,6,7$ e 8 demonstram que todas as sangrias apresentaram respostas detectáveis.

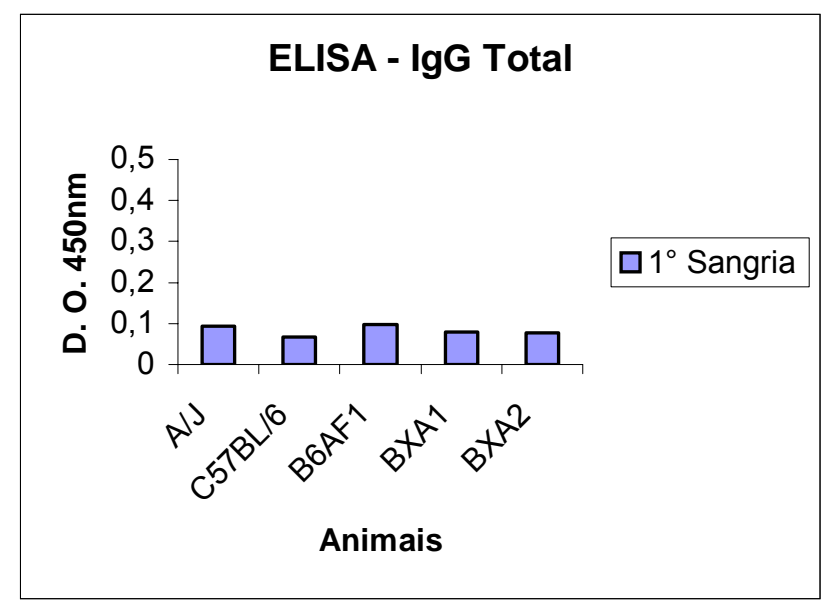

GRÁFICO 2 - Ensaio imunoenzimático para a produção de anticorpos específicos (IgG Total) com soro proveniente da $1^{\circ}$ sangria. 


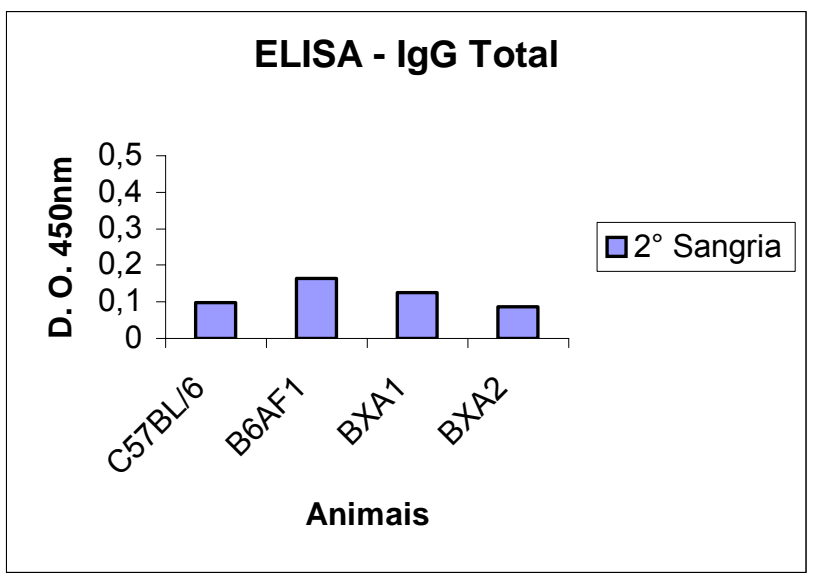

GRÁFICO 3 - Ensaio imunoenzimático para a produção de anticorpos específicos (IgG Total) com soro proveniente da $2^{\circ}$ sangria.

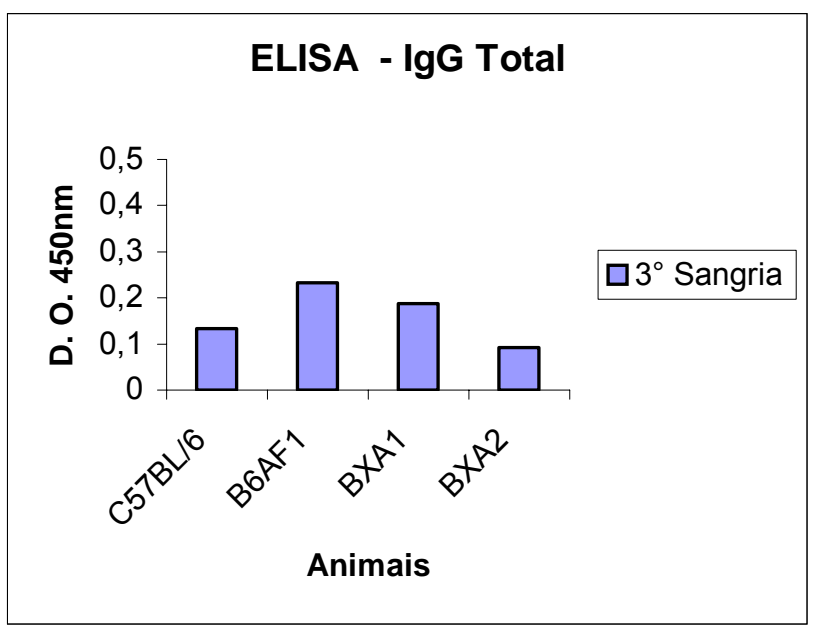

GRÁFICO 4 - Ensaio imunoenzimático para a produção de anticorpos específicos (IgG Total) com soro proveniente da $3^{\circ}$ sangria.

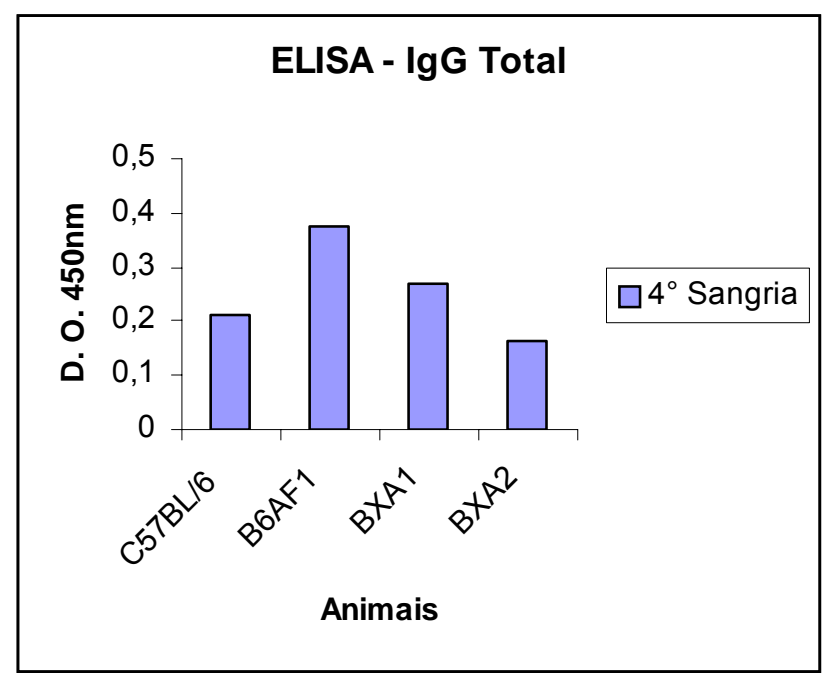

GRÁFICO 5 - Ensaio imunoenzimático para a produção de anticorpos específicos (IgG Total) com soro proveniente da $4^{\circ}$ sangria. 


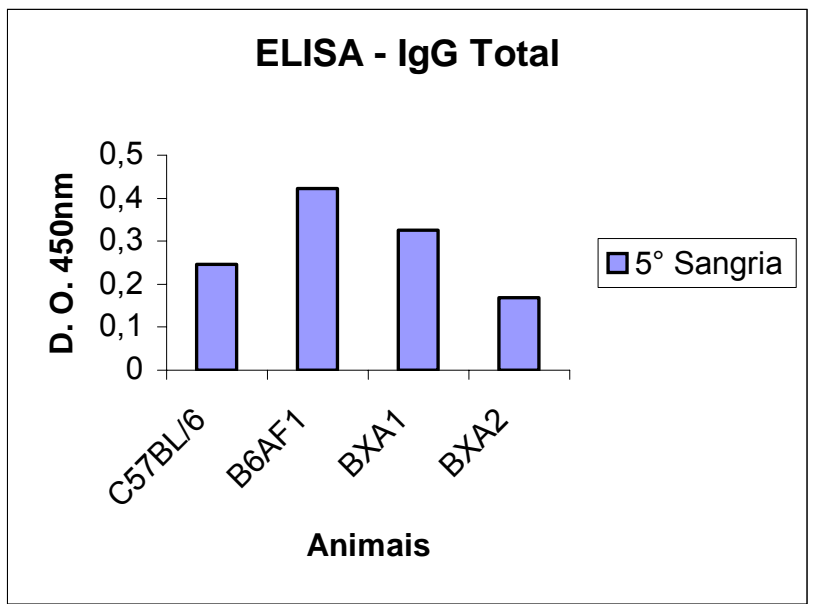

GRÁFICO 6 - Ensaio imunoenzimático para a produção de anticorpos específicos (IgG Total) com soro proveniente da $5^{\circ}$ sangria.

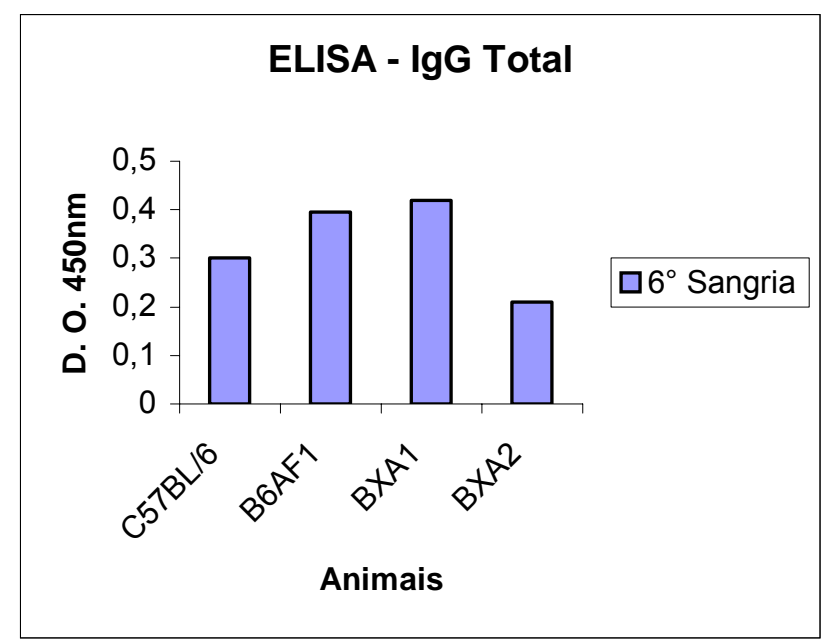

GRÁFICO 7 - Ensaio imunoenzimático para a produção de anticorpos específicos (IgG Total) com soro proveniente da $6^{\circ}$ sangria.

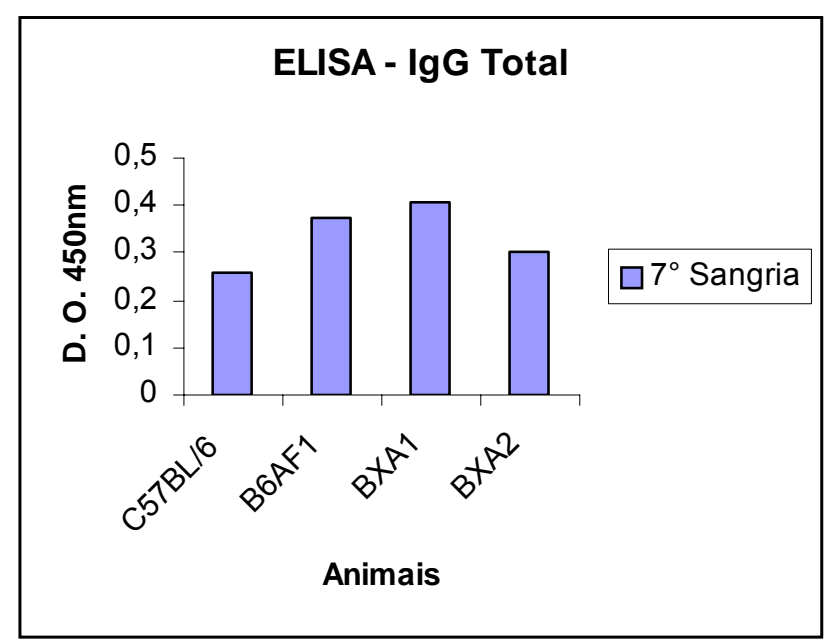

GRÁFICO 8 - Ensaio imunoenzimático para a produção de anticorpos específicos (IgG Total) com soro proveniente da $7^{\circ}$ sangria. 
De acordo com os resultados encontrados optou-se trabalhar com a $1^{\circ}$ sangria pois, somente nela é possível demonstrar o padrão de resposta encontrado na linhagem $A / J$ que morre num período inferior a 11 dias após a infecção, e com a $6^{\circ}$ sangria pois nesta encontrou-se um padrão superior entre as demais sangrias testadas, exceto para linhagem B6AF1 que apresentou pequeno declínio em sua resposta.

Os gráficos abaixo representados mostram os resultados encontrados com os testes realizados para avaliação de anticorpos das subclasses IgG1, IgG2a e lgG2b realizados com soros provenientes da $1^{\circ}$ e $6^{\circ}$ sangrias diluídos 1:50.

O ensaio imunoenzimático com a linhagem de animais $A / J$, foi realizado com soro proveniente da $1^{\circ}$ sangria após a infecção por $T$. cruzi.

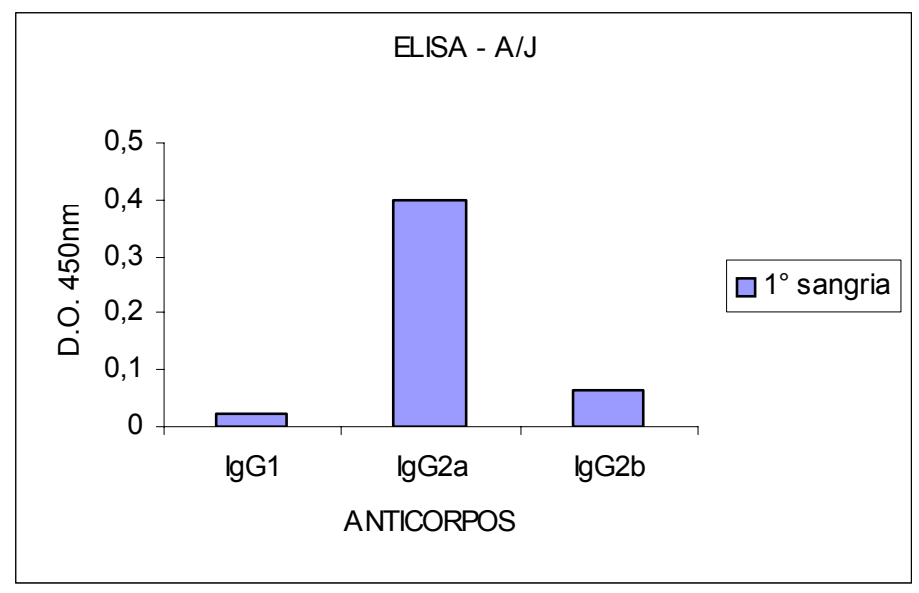

GRÁFICO 9 - Ensaio imunoenzimático para avaliação da produção de anticorpos específicos (IgG1, $\lg 22 a$ e $\operatorname{lgG} 2 b$ ) com soro proveniente da $1^{\circ}$ sangria de animais da linhagem $A / J$. 
O ensaio imunoenzimático com a linhagem de animais C57BL/6, foi realizado com soro proveniente da $1^{\circ}$ e da $6^{\circ}$ sangria após a infecção por T. cruzi.

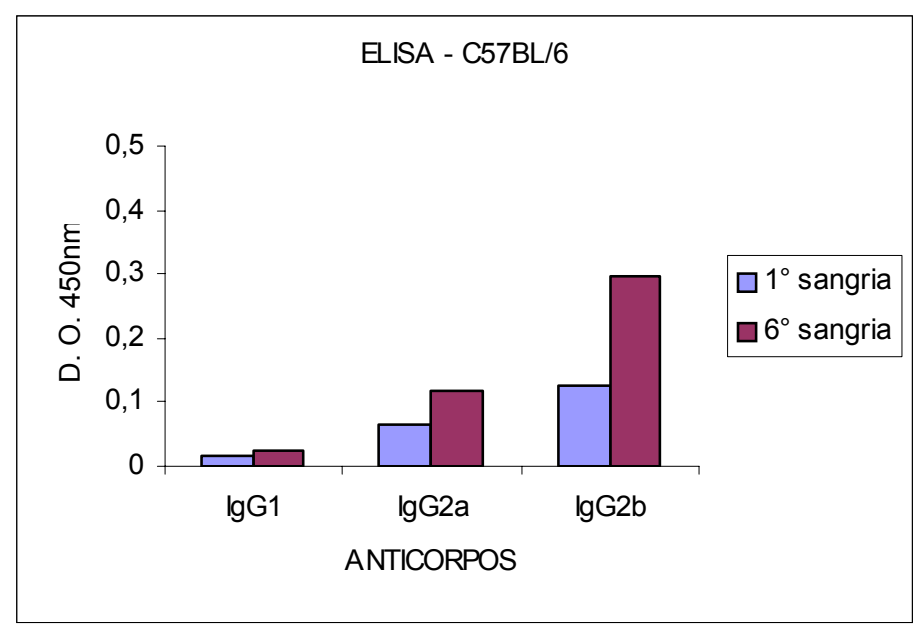

GRÁFICO 10 - Ensaio imunoenzimático para avaliação da produção de anticorpos específicos (IgG1, $\lg 2 \mathrm{a}$ e $\lg \mathrm{G} 2 \mathrm{~b}$ ) com soro proveniente da $1^{\circ}$ e $6^{\circ}$ sangrias de animais da linhagem C57BL/6.

O ensaio imunoenzimático com a linhagem de animais B6AF1, foi realizado com soro proveniente da $1^{\circ}$ e da $6^{\circ}$ sangria após a infecção por T. cruzi.

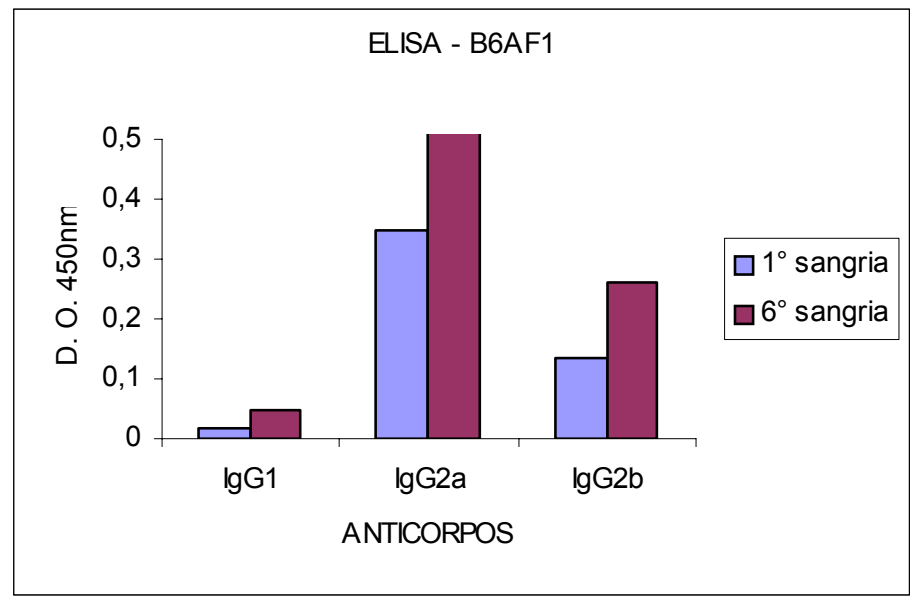

GRÁFICO 11 - Ensaio imunoenzimático para avaliação da produção de anticorpos específicos (IgG1, $\lg 2 a$ e $\lg (2 b)$ com soro proveniente da $1^{\circ}$ e $6^{\circ}$ sangrias de animais da linhagem B6AF1. 
O ensaio imunoenzimático com a linhagem de animais BXA1, foi realizado com soro proveniente da $1^{\circ}$ e da $6^{\circ}$ sangria após a infecção por $T$. cruzi.

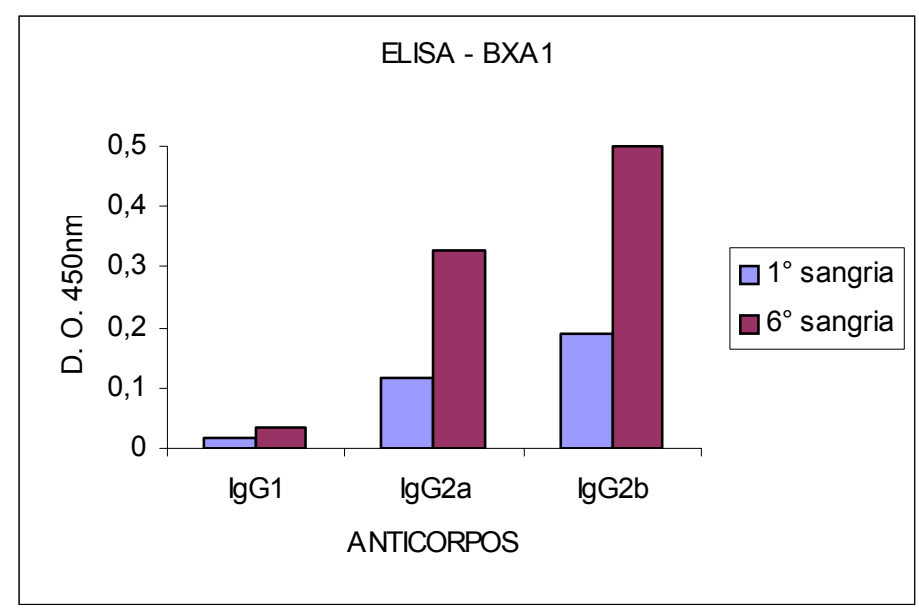

GRÁFICO 12 - Ensaio imunoenzimático para avaliação da produção de anticorpos específicos (IgG1, $\lg$ Ga e $\lg \mathrm{G} 2 \mathrm{~b}$ ) com soro proveniente da $1^{\circ}$ e $6^{\circ}$ sangrias de animais da linhagem BXA1.

O ensaio imunoenzimático com a linhagem de animais BXA2, foi realizado com soro proveniente da $1^{\circ}$ e da $6^{\circ}$ sangria após a infecção por $T$. cruzi.

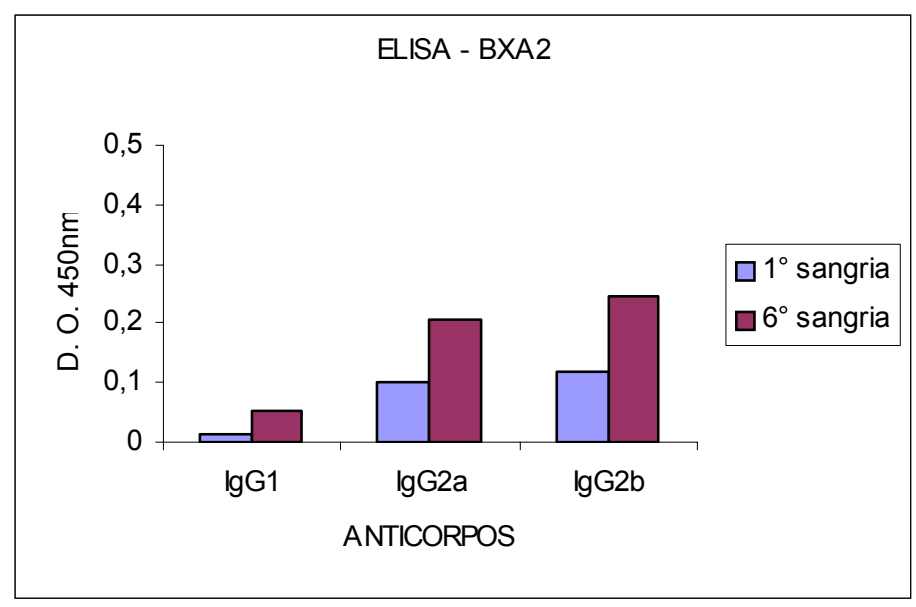

GRÁFICO 13 - Ensaio imunoenzimático para avaliação da produção de anticorpos específicos (IgG1, $\lg 2 \mathrm{a}$ e $\lg \mathrm{g} 2 \mathrm{~b}$ ) com soro proveniente da $1^{\circ}$ e $6^{\circ}$ sangrias de animais da linhagem BXA2. 


\section{6 - DISCUSSÃO}

A maior parte dos conhecimentos acerca da doença de Chagas deriva dos ensaios realizados com modelos animais, sendo freqüente o uso de camundongos. As linhagens isogênicas de camundongos são, em geral, a primeira escolha para o desenvolvimento de programas de investigação genética, uma vez que, por apresentarem uma homozigose em cerca de $99 \%$ dos alelos, respondem de forma homogênea oferecendo resultados universais e reprodutivos (BECK et al, 2000; PASSOS, 2003).

Os primeiros experimentos relacionando a importância da constituição genética do hospedeiro no controle da infecção experimental por $T$. cruzi, data do final da década de setenta, quando pesquisadores, empregando-se de acasalamentos programados entre linhagens isogênicos de camundongos resistentes e susceptíveis, descreveram a importância do lócus $\mathrm{H} 2$, presente no cromossomo 17 destes animais. Possivelmente, em razão de dificuldades técnicas encontradas não puderam ser aprofundadas, restando porém, esclarecimentos da importância do genoma dos animais no controle da infecção (Passos, 2003).

Graefe e colaboradores (2003) mostraram que diferentes linhagens isogênicas de camundongos apresentam comportamento diferenciado, após a inoculação com o T. cruzi.

Corroborando esses dados, Passos e colaboradores (2002) mostraram que diferentes concentrações de $T$. cruzi eram capazes de selecionar animais quanto à resistência a este protozoário. A linhagem C57BL/6 foi considerada resistente pois sobreviveu a um período superior a 30 dias após o inóculo de $10^{4}$ tripomastigotas. A linhagem $A / J$ foi considerada susceptível, pois, seus representantes não sobreviveram a um período superior a 11 dias após o inóculo de $10^{1}$ tripomastigotas.

Para determinar o comportamento frente ao $T$. cruzi, de uma progênie derivada dessas linhagens parentais (C57BL/6 e A/J), foram realizados acasalamentos programados e os descendentes foram submetidos a diferentes concentrações de tripomastigotas por animal. Esta população de híbridos B6AF1 tem a característica de ser homogênea, possibilitando um padrão único de resposta, uma vez que cada 
metade de sua constituição genética corresponde aos parentais resistente e susceptível (PASSOS, 2003).

Os resultados obtidos demonstram que a população de animais híbridos B6AF1, se comporta de maneira semelhante àquela observada com o parental de fenótipo resistente (C57BL/6) onde o valor do $X^{2}$ para estes resultados foi de: $X^{2}=0,39$; $p=0,53117$, indicando que a resistência obedece a um padrão de herança de caráter dominante. A comparação entre os animais híbridos (B6AF1), e a linhagem parental de fenótipo susceptível (A/J) demonstra existir uma diferença acentuada entre estas duas populações, indicando que o fenótipo resistente está sendo transmitido para a progênie, mostrando que os mecanismos envolvidos com o controle da doença aguda ficaram preservados nos animais B6AF1, possibilitando a sua sobrevivência.

Estes resultados quando comparados aos achados de Graefe et al, (2003) indicam que, na linhagem $A / J$ a presença alelos recessivos podem ser responsáveis pela susceptibilidade murina ao T. cruzi, ou então, que a resistência ao parasito poderia depender da ação conjunta de múltiplos genes.

O presente trabalho aborda o padrão de resposta de imunoglobulinas das diferentes linhagens de camundongos que foram infectados com a cepa $Y$ de $T$. cruzi e selecionados quanto à resistência por Passos (2003).

Para a avaliação do padrão de resposta de imunoglobulinas, amostras dos soros das linhagens A/J, C57BL/6, B6AF1, BXA1 e BXA2 foram analisados pelo método de ELISA.

De acordo com os resultados dos ensaios imunoenzimáticos apresentados, pode-se dizer, que de um modo geral todas as linhagens apresentaram um padrão de resposta superior quando testadas com IgG2a e lgG2b, se comparados com os resultados encontrados quando testados com IgG1. Imunoglobulinas IgG1 implicam num padrão de resposta do tipo Th2 que expressa respostas imunológicas alérgicas, enquanto que imunoglobulinas IgG2 implicam num padrão de resposta Th1 que expressa respostas imunológicas celulares.

A imunidade celular é o principal mecanismo de defesa do hospedeiro contra parasitos intracelulares, mas, anticorpos e complemento podem participar desse 
mecanismo, revelando que o fenômeno da resistência é complexo e depende da ação de diferentes células e moléculas (WOODMAN et al, 1998; Passos, 2003).

Os neutrófilos, que são as primeiras células a migrarem para o local da infecção, podem destruir os parasitos através da ação de produtos do metabolismo oxidativo, como o peróxido de hidrogênio $\left(\mathrm{H}_{2} \mathrm{O}_{2}\right)$, atividade enzimática e produção de óxido nítrico (MURRAY et al, 1983; PEARSON e STEIGBIGEL, 1981). Os neutrófilos infectados começam a secretar quimiocinas como IL-8 (SCAPINI et al, 2000), molécula importante para atrair mais neutrófilos e macrófagos para o local da infecção.

A produção de óxido nítrico (NO) como uma via efetora comum de defesa do macrófago contra parasitas intracelulares tem sido bem documentada (GREEN et al, 1991).

De um modo geral a resposta imune é além de complexa é integrada, dependendo da ação de diferentes genes para ser efetiva. Entretanto o nível de expressão desses genes pode determinar o controle da fase aguda na doença de Chagas.

Assim, INF- $\gamma$ produzido por células NK ativadas, passa a desenvolver um papel central na resistência da fase aguda da infecção pela cepa $Y$ de T. cruzi, pois ativa os macrófagos, acentuando a resposta Th1.

Esta citocina produzida principalmente por células CD4+ do tipo Th1, e por células "natural killer" (NK), estimuladas por IL-12 (BOGDAN et al, 2000). A interleucina-12 (IL-12) tem sido apontada como um dos mais importantes componentes da fase inicial da infecção por T. cruzi. A IL-12 é produzida primariamente por células apresentadoras de antígeno (monócitos, macrófagos, células dendríticas e células B) e sua principal atividade biológica é sobre as células T e NK, nas quais ela estimula a produção de citocinas, principalmente IFN- $\gamma$, proliferação celular e citotoxicidade (WHO, 2001).

Quando um macrófago ativado ou outra célula apresentadora de antígeno inicia a produção e a exocitose de IL-1, estimula os linfócitos Th a aumentar o seu metabolismo interno e produzir citocinas (interleucinas e interferon). Os linfócitos Th em grande número produzem interferon $\gamma$ que além de ativar a fagocitose, ativa a 
expressão do MHC-classe II nos macrófagos. O MHC (Major Histocompatibility Complex) é o complexo de histocompatibilidade principal, que identifica e se liga aos demais linfócitos Th. O MHC-classe II é um antígeno próprio dos macrófagos que quando expresso, se liga aos linfócitos Th que indicam ao sistema imunológico que o organismo está sendo atacado por antígenos invasores. O CD4 é o receptor de MHC-classe II presente nos linfócitos Th e que faz a ligação das células $T$ com os macrófagos. Quando o linfócito Th se liga ao macrófago (ligação CD4-MHCII) o antígeno ligado lateralmente ao $\mathrm{MHCll}$ é apresentado pelos macrófagos e reconhecido pelo TCR, que é um receptor presente em todos os linfócitos $T$, e que desencadeia um processo de reações químicas que resultam na ativação dos linfócitos Th. Eles aumentam o metabolismo, e sofrem a expansão clonal específica, sob estímulo da IL-2, formando uma população enorme de linfócitos Th específicos.

A partir daí, os linfócitos $T$ desencadeiam a resposta imunológica específica celular ou humoral ou ambas dependendo do antígeno.

Pesquisadores demonstraram que células TCD4+ podem ser subdivididas em subpopulações baseadas no tipo de citocinas que elas produzem. As células $T$ "helper" tipo 1 (Th1) produzem IFN- $\gamma$ e interleucina-2 (IL-2), fator estimulador de colônias de macrófagos e granulócitos, interleucina-3 (IL-3) e linfotoxina (TNF- $\beta$ ), e são responsáveis pela imunidade mediada por células, além de estimular a produção de anticorpos da classe lgG2a (MOSMANN et al, 1989).

Células T "helper" tipo 2 (Th2) produzem interleucina-4 (IL-4), interleucina-5 (IL-5), interleucina-10 (IL-10) e interleucina-13 (IL-13), e mediam a imunidade humoral e as reações alérgicas. A IL-4 está relacionada com a produção de anticorpos da classe IgE, IgG1 e IgG4; e a IL- 5 é importante para diferenciação, multiplicação e ativação de eosinófilos (MOSMANN et al, 1989).

Níveis de óxido nítrico produzidos por macrófagos ativados por interferongama (IFN- $\gamma$ ) ou pelo fator de necrose tumoral alfa (TNF- $\alpha$ ) estão relacionados com a resistência à infecção, uma vez que macrófagos provenientes de linhagens resistentes de camundongos produzem níveis significativamente mais altos de NO do que macrófagos provenientes de linhagens de camundongos susceptíveis (LIEW et al, 1991). Estudos realizados por Murray e Nathan (1999), demonstraram que 
camundongos não possuidores do gene de nitrato sintetase (enzima que catalisa síntese de NO) não têm capacidade de controlar a infecção.

Animais da linhagem $\mathrm{A} / \mathrm{J}$ apresentaram padrão de resposta lgG2a, superior àquele apresentado pela linhagem C57BL/6 e pelo híbrido B6AF1 quando infectados pelo T.cruzi, revelando uma resposta celular imediata. Porém, segundo Liew e colaboradores (1991), esses animais possuem deficiência na produção de IFN- $\gamma$ e IL12 o que pode ter acarretado a falta de controle da infecção e conseqüente morte de seus representantes.

Segundo Heinzel (1991), camundongos susceptíveis como o A/J possuem expressão de IL-4 nas células de seus linfonodos. Em contraste, camundongos da linhagem C57BL/6, geneticamente resistentes, expressam IFN- $\gamma$, fornecendo 0 padrão Th1 de resposta.

Os animais da linhagem C57BL/6 apresentaram IgG2b mais elevada que as outras linhagens, revelando uma resposta imunológica celular mais tardia. Esses animais, por possuírem altos níveis de IFN- $\gamma$ e IL-12, conseguem controlar a infecção na fase aguda. Segundo Oliveira e colaboradores (1989), esses altos níveis de IFN- $\gamma$ durante a fase crônica da infecção, pode favorecer a cura ou influenciar o desenvolvimento da forma cardíaca da doença.

Em camundongos resistentes (C57BL/6) células TCD4+ do tipo Th1 produzem IFN- $\gamma$ que ativa o óxido nítrico sintetase (iNOS ou NOS2), levando ao estímulo da ação microbicida mediada pelo óxido nítrico (NO). A liberação de NO leva a morte da maioria dos parasitos nos macrófagos (BOGDAN et al, 2000; BRANDONISIO et al, 2002).

Animais susceptíveis (A/J) podem apresentar altos níveis de IL-4 e IL-5, em conseqüência, apresentam baixos níveis de IFN- $\gamma$, impedindo assim a eliminação do parasito, apesar de não ocorrer o aparecimento de células Th2.

A IL-12 desempenha um papel importante na diferenciação e expansão das células TCD4+ do tipo Th1 e é importante para o padrão de resistência do camundongo (SCHARTON et al, 1995; SCOTT \& KAUFMANN, 1991). As células NK ativadas por IL-12 são a fonte inicial de IFN- $\gamma$ na infecção por $T$. cruzi nos camundongos resistentes. Assim, a produção endógena de IL-12 é necessária para o 
controle da infecção, presumivelmente, através da indução de IFN- $\gamma$, requerida para conter a expansão do parasito (SYPEK et al, 1993).

Tem-se demonstrado que a utilização de IL-12 associada com uma droga tripanossomicida pode levar a uma alteração na resposta imune, podendo até curar a infecção em animais susceptíveis (NABORS et al, 1995).

Animais da linhagem B6AF1 apresentam um padrão de resposta inicial semelhante ao seu parental original $A / J$, ou seja, apresentam como resposta principal lgG2a, porém, esses animais potencialmente podem controlar a infecção, pois herdaram de seu parental original C57BL/6 regiões relacionadas com a resistência e é por isso que a resposta lgG2b é semelhante àquela encontrada nos animais da linhagem C57BL/6. Esses animais, portanto, são mais resistentes que seu parental original C57BL/6.

Para a realização dos ensaios imunoenzimáticos das linhagens recombinantes isogênicas foram utilizados soros somente das linhagens BXA1 e BXA2 que foram consideradas respectivamente resistentes e susceptíveis à infecção pela cepa Y de T. cruzi.

Estas linhagens recombinantes isogênicas (BXA1 e BXA2) oriundas do Jackson Laboratory foram mantidas no CEMIB/UNICAMP e posteriormente trazidas para o IPEN. Após o inoculo com concentração de $10^{4}$ tripomastigotas, levantou-se a hipótese de que algumas regiões importantes para resistência foram preservadas durante a obtenção dessas linhagens.

Animais BXA1 apresentam um padrão de resposta inicial semelhante aos animais da linhagem C57BL/6, ou seja, tem como resposta principal lgG2b, porém apresentam IgG2a em quantidade significativa, sendo, no entanto, inferior àquela apresentada pela linhagem $\mathrm{A} / \mathrm{J}$. Isso mostra que o padrão de resposta por ela apresentado preserva tanto traços da linhagem resistente como da susceptível. Assim, essa linhagem apresenta um padrão de resposta intermediário, não sendo tão resistente quanto os representantes das linhagens B6AF1 e C57BL/6, mas, resistindo à infecção por $T$. cruzi por um período superior aquele apresentado pela linhagem A/J. 
Animais da linhagem BXA2 apresentam em sua resposta IgG2a e IgG2b quase na mesma proporção. Esses animais podem ser considerados susceptíveis a infecção por $T$. cruzi, porém permanecem vivos durante um período superior àquele apresentado pela linhagem $\mathrm{A} / \mathrm{J}$, provavelmente por produzirem uma resposta tardia decorrente de IgG2b, contrastando com a linhagem parental de fenótipo susceptível que não consegue desenvolver este mecanismo. Assim, não resistem à infecção de forma tão acentuada quanto os animais das linhagens B6AF1 e C57BL/6, mas, conseguem controlar a infecção e sobreviver a ela por um período superior a 30 dias, indicando a importância da subclasse lgG2b na resistência à infecção por $T$. cruzi. 


\section{7 - CONCLUSÕES}

- Todas as linhagens infectadas com T.cruzi apresentaram padrão de resposta imunológica celular.

- A linhagem C57BL/6 infectada com T. cruzi apresentou padrão de resposta predominantemente $\lg \mathrm{g} 2 \mathrm{~b}$

- A linhagem A/J infectada com T. cruzi apresentou padrão de resposta predominantemente IgG2a.

- Os animais da linhagem B6AF1 são mais resistentes à infecção por T. cruzi que seu parental original C57BL/6. Sua resposta imunológica apresenta traços tanto do parental original $\mathrm{A} / \mathrm{J}$ quanto do $\mathrm{C} 57 \mathrm{BL} / 6$.

- Os animais da linhagem BXA1 podem ser considerados resistentes à infecção por T. cruzi, mas não apresentam o mesmo controle sobre a infecção apresentado pelos animais das linhagens B6AF1 e C57BL/6.

- Os animais da linhagem BXA2 podem ser considerados susceptíveis à infecção por $T$. cruzi, mas controlam a infecção por um período maior, sobrevivendo assim, por mais tempo que os animais da linhagem $A / J$.

- O padrão de resposta do tipo lgG2b está diretamente relacionado com a resistência dos camundongos à cepa $Y$ de $T$. cruzi.

- O padrão de resposta IgG2a isolado não confere resistência à cepa $Y$ de $T$. cruzi. 


\section{REFERÊNCIAS BIBLIOGRÁFICAS}

ALBARRACIN, H. V.; CARVALHO, M. E.; NASCIMENTO, E. M. M.; RODRIGUES, V. L. C. C.; CASANONA, C. \& BARATA, J. M. S. Chagas disease in areas of recent occupation in Cochabamba, Bolívia. Revista Saúde Pública, São Paulo, 33:201207, 1999.

ALVES, J. B. Aspectos da resposta imune frente a antígenos protéicos irradiados com ${ }^{60}$ Co. 2004. Tese (Mestrado) - Instituto de Pesquisas Energéticas e Nucleares, São Paulo.

AVILA, H.; PEREIRA, B. J.; THIEMANN, O.; PAIVA, E.; DEGRAVE, W.; MOREL, M. C. \& SIMPSON, L. Detection of Trypanosoma cruzi in blood specimes of chronic chagasic patients by: Polimerase Chain Reaction amplification of kinetoplast minicircle DNA: comparison with serology and xenodiagnosis. J. Clin. Microbiol, 31: 2421-2426, 1993.

BECK, J.A.; LLOYD, S.; HAFEZPARASAT, M.; PIERCE, M. L.; EPPIG, J.T.; FESTING, F.W.; FISCHER, M.C. Genealogies of inbred strains. Nature Genetics. 24: 23 - 25, 2000.

BITTENCOURT, A. L. Actual aspect and epidemiological significance of congenital transmission of Chagas' disease. Mem. Inst. Oswaldo Cruz, 1984; 79 (supl.) 133-137.

BOGDAN, C.; ROLLINGHOFF, M.; DIEFENBACH, A. The role of nitric oxide in innate immunit. Immunology Review 173: 17-26, 2000.

BRADONISIO, O.; PANARO, M. A.; FUMAROLA, I.; SISTO, M.; LEOGRAND, D.; ACQUAFREDDA, A.; SPINELLI, R.; MITOLO, V. Macrophage chemotactic protein1 and macrophage inflamatory protein-1 alpha induce nitric oxide release and enhance parasite killing in Leishmania infantum-infected human macrophages. Clinical Experimental Medicine 2: 125-129, 2002.

BRENER, Z. Immunity to Trypanosoma cruzi. Adv. Parasitol. 18: 247 - 291, 1980.

CASTRO, L. P.; CUNHA, A. S.; REZENDE, J. M. Protozooses humanas. São Paulo: Fundo Editorial BYK., p. 38-67, 1994.

CHATELAIN, R.; VARKILA, K.; COFFMAN, R. L. IL-4 induces a Th2 response in Leishmania major-infected mice. Journal of Immunology 148: 1182-1187, 1992.

CORSINI, A.C.; COSTA, M.G.; OLIVEIRA, O.L.; CAMARGO, I.J.; STELINI, A. JR. Susceptibility of inbred strain mice to Trypanosoma cruzi strain Y. Rev. Inst. Med.Trop. São Paulo. 22(4): 192 - 6, 1980. 
DELVES, P. J.; ROITT, I. M. The Immune System - First of two parts. Advances in Immunology, 343:37-49, 2000.

FESTING, M.F.W. Warning: the use of heterogeneous mice may seriously damage your research. Neurobiol Aging. 20(2):237-44, 1999.

FORTIN, A.; STEVENSON, M.M.; GROS, P. Complex genetic control of susceptibility to malaria in mice. Genes and Immunology. 3: 177-186, 2002.

GODARD, A.L.B.; GUENET, J. L.Genética de camundongos: modelos animais de doenças humanas. Biotecnologia Ciência e Desenvolvimento. 2 (9): 96-100, 1999.

GOLDENBERG, S.; KRIEGER, M.A. Doença de Chagas: Novas perspectivas no diagnóstico imunológico. Biotecnologia Ciência e Desenvolvimento. 1(1):26-27, 1997.

GRAEFE, S.E.B.; MEYER, B.S.; MYHSOK, B. M.; RÜSCHENDORF, F.; DROSTEN, C.; LAUE, T.; RNBERG, P. N; FLEISCHER, B. Murine susceptibility to Chagas' disease maps to chromosomes 5 and 17. Genes and Immunity. 4: 321-325, 2003.

GREEN, S. J.; NACY, C. A.; MELTZER, M. S. Cytokine-induced synthesis of nitrogen oxides in macrophages: a protective host response to Leishmania and other intracellular pathogens. Journal of Leukocyte Biology 50: 93- 103, 1991.

HEINZEL, F. P.; SADICK, M. D.; MUTAH, S. S. \& LOCKSLEY, R. M. Production of INF $\gamma$, IL-2, IL-4 and IL-10 by CD4+ lymphocytes in vivo during healing and progressive murine leishmaniasis. Proceedings of the National Academy of Science of the United States of America. 88:7011-7015,1991.

LIEW, F. Y.; LI, Y.; MOSS, D.; PARKINSON. C.; ROGERS, M. V.; MONCADA, S. Resistance to Leishmania major infection correlates with the induction of nitric oxide syntase in murine macrophages. European Journal of Immunology 21: 30093014, 1991.

MARTINS, G.A.; VIEIRA, L.Q.; CUNHA, F.Q.; SILVA, J.S. Gamma interferon modulates CD95 (Fas) and CD95 ligand (Fas-L) expression and nitric oxideinduced apoptosis during the acute phase of Trypanosoma cruzi infection: a possible role in immune response control. Infect Immun. 67(8):3864-71, 1999.

MELVOLD, R.W. Inbred, congenic, recombinant-inbred and mutant mouse strains. IN:Genetics and Molecular Immunology. (3 Ed.) 3(106.1): 106.20, 1986.

MOSMANN, T. R. \& COFFMAN, R. L. TH1 and TH2 cells: different patterns of lynphokine secretion lead to different functional properties. Annual Review of Immunology 7: 145-173, 1989. 
MURRAY, H. W. \& NATHAN, C. F. Macrophage microbicidal mechanisms in vivo: reactive nitrogen versus oxygen intermediates in the killing of intracellular visceral Leishmania donovani. Journal of Experimental Medicine 189: 741-746, 1999.

NABORS, G. S.; AFONSO, L. C.; FARREL, J. P.; SCOTT, P. Switch from a type 2 to a type $1 \mathrm{~T}$ helper cell response and cure of established Leishmania major infection in mice is induced by combined therapy with interleukin 12 and Pentostam. Proceeding National Academy Science USA 92: 314203146,1995.

NABORS, G.S., TARLETON, R.L. - Differential control of IFN- $\gamma$ and IL2 production during Trypanosoma cruzi infection. J. Immunol. 146 :3591, 1991.

NEVES, J. Diagnóstico e tratamento das doenças infecciosas e parasitárias. 2. ed. Rio de Janeiro: Guanabara Koogan., p. 694-722, 1983.

NETO, E. C. Novos conhecimentos na patogênese da doença de Chagas. Biotecnologia Ciência e Desenvolvimento. 2 (9):19-22, 1999.

OLIVEIRA, L.M. B.; GOMES, J.A.; ROCHA, M.O.; MOREIRA, M.C.; LEMOS, E.M.; LUZ, Z.M.; PEREIRA, M.E.; COFFMAN, R.L.; DIAS, J.C.; CANÇADO, J.R.; GAZINELLI, G.; OLIVEIRA, R. C. IFN-gamma in human Chagas' disease: protection or pathology? Braz. J. of Med. and Biol. Res. 31(1): 127 -131, 1998.

OLIVEIRA, M.A.P.; SANTIAGO, H.C.; LISBOA, C.R.; CERAVOLLO, I.P.; TRINCHIERI, G.; GAZINELLI, R.T.; VIEIRA, L.Q. Leishmania sp: Comparative Study with Toxoplasma gondii and Trypanosoma cruzi in Their Ability to Initialize IL-12 and IFN -g Synthesis. Experimental Parasitology. 95: 96-105, 2000.

PARKIN, J.; COHEN, B. An Overview of the Immune System. Lancet, 357:177789, 2001.

PASSOS, L.A.C.; SAKURADA, J.; GUARALDO, A.M.A.; ORTIZ, S.C.B.C.; RANGEL, H.A.; GUENET, J. L. Chagas: Fenômeno da Resistência. Biotecnologia Ciência e Desenvolvimento. (5): 26-31, 2002.

PASSOS, L. A. C. Análise do determinismo Genético da resistência de camundongos infectados experimentalmente com a cepa $Y$ de Trypanosoma cruzi. 2003. Tese (Doutorado) - Instituto de Biologia, Campinas.

PEARSON, R. D. \& STEIGBIGEL, R. T. Phagocytosis and killing of the protozoan Leishmania donovani by human polymorphonuclear leukocytes. Journal of Immunology 127: 1438-1443, 1981. 
RANGEL, H.A.; VERIMAUD, L.; CAMARGO, I.J.B.; GIGLIOLI, R.; SAKURADA, J.K. Murine virus contaminant of Trypanosoma cruzi experimental infection. Rev. Inst. Med. Trop. São Paulo 36(5):423 - 431, 1994.

SCAPINI, P.; LAPINET, V. J. A.; GASPERINI, S.; CALZETTI, F.; BAZZONI, F.; CASSATELLA, M. A. The neutrophile as a cellular source of chemokines. Immunology Review 177: 195-203, 2000.

SCOTT, P. \& KAUFMANN, S. H. The role of T-cell subsets and cytokines in the regulation of infection. Immunology Today 12: 346-348, 1991.

SHARP, M; Manual Merch: Saúde para a Família. Biologia do Sistema Imune, 2004. Cap. 167.

SHARTON, K. T.; AFONSO, L. C.; WYSOCKA, M.; TRINCHIERI, G.; SCOTT, P. IL12 is required for natural killer cell activation and subsequent $T$ helper 1 cell development in experimental leishmaniasis. Journal of Immunology 154: 53205330, 1995.

SYPEK, J. P.; CHUNG, C. L.; MAIOR, S. E.; SUBRAMANYAM, J. M.; GOLDMAN, S. J.; SIEBURTH, D. S.; WOLF, S. F.; SCHAUB, R. G. Resolution of cutaneous Leishmaniasis: interleukin 12 initiates a protective $T$ helper type 1 immune response. Journal Experimental Medicine 177: 1797-1802,1993.

TEIXIERA, A.T. Doença de Chagas e outras doenças por Tripanossomos. Ed. Universidade de Brasília, 1987, p.15-89.

VYSE, T.J., TODD, J.A. Genetic Analysis of Autoimmune Disease. Cell. 85: 311318, 1996.

WHO. World Health Organization, Geneve, 2001.

WHO. Global defense against the infectious disease threat. Ed. Mary Kay Kindhauser. World Health Organization, Geneve, 2003.

WOODMAN, R. C.; JOHNSTON, B.; HICKEY, M. J.; TEOH, D.; REINHARDT, P.; POON, B. Y.; KUBES, P.; The functional paradox of CD43 in leukocyte recruitment: a study using CD43-deficient mice. Journal Experimental Medicine.188: 2181-2186, 1998.

WRIGHTSMAN, R.; KRASSNER, S.M.; WATSON, J. Genetic Control of Responses to Trypanosoma cruzi in Mice: Multiple Genes Influencing Parasitemia and Survival. Infection and Immunity. 36(2):637-644, 1982. 